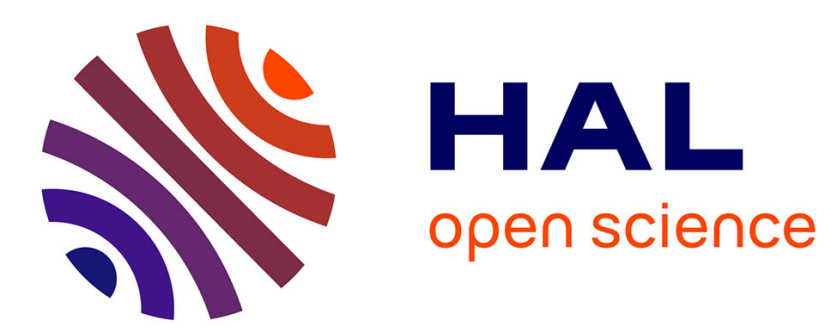

\title{
Regional estimation of catchment-scale soil properties by means of streamflow recession analysis for use in distributed hydrological models
}

\author{
O. Vannier, Isabelle Braud, S. Anquetin
}

\section{- To cite this version:}

O. Vannier, Isabelle Braud, S. Anquetin. Regional estimation of catchment-scale soil properties by means of streamflow recession analysis for use in distributed hydrological models. Hydrological Processes, 2014, 28 (26), pp.6276-6291. 10.1002/hyp.10101 . hal-01247189

\author{
HAL Id: hal-01247189 \\ https://hal.science/hal-01247189
}

Submitted on 21 Dec 2015

HAL is a multi-disciplinary open access archive for the deposit and dissemination of scientific research documents, whether they are published or not. The documents may come from teaching and research institutions in France or abroad, or from public or private research centers.
L'archive ouverte pluridisciplinaire HAL, est destinée au dépôt et à la diffusion de documents scientifiques de niveau recherche, publiés ou non, émanant des établissements d'enseignement et de recherche français ou étrangers, des laboratoires publics ou privés. 


\title{
REGIONAL ESTIMATION OF CATCHMENT-SCALE SOIL PROPERTIES BY
}

MEANS OF STREAMFLOW RECESSION ANALYSIS FOR USE IN DISTRIBUTED HYDROLOGICAL MODELS

\author{
VANNIER Olivier $^{1}$, BRAUD Isabelle ${ }^{2}$, ANQUETIN Sandrine $^{1}$
}

${ }^{1}$ LTHE, UMR 5564 - Université de Grenoble, BP53, Grenoble Cedex 9 F-38041, France ${ }^{2}$ IRSTEA, UR HHLY (Hydrology-Hydraulics), 5 Rue de la Doua, CS 70077, 69626 Villeurbanne cedex, France 


\section{ABSTRACT}

The estimation of catchment-scale soil properties, such as water storage capacity and hydraulic conductivity, is of primary interest for the implementation of distributed hydrological models at the regional scale. This estimation is generally done on the basis of information provided by soil databases. However, such databases are often established for agronomic uses and generally do not document deep weathered rock horizons (i.e. pedologic horizons of type $\mathrm{C}$ and deeper), which can play a major role in water transfer and storages. Here we define the Drainable Storage Capacity Index (DSCI), an indicator that relies on the comparison between cumulated streamflow and precipitation to assess catchment-scale storage capacities. DSCI is found to be reliable to detect underestimation of soil storage capacities in soil databases. We also use the streamflow recession analysis methodology defined by Brutsaert and Nieber in 1977 to estimate water storage capacities and lateral saturated hydraulic conductivities of the non-documented deep horizons. The analysis is applied to a sample of twenty-three catchments $\left(0.2 \mathrm{~km}^{2}-291 \mathrm{~km}^{2}\right)$ located in the CévennesVivarais region (south of France). For a regionalisation purpose, the obtained results are compared to the dominant catchment geology and present a clear hierarchy between the different geologies of the area. Hard crystalline rocks are found to be associated with the thickest and less conductive deep soil horizons. Schist rocks present intermediate values of thickness and of saturated hydraulic conductivity, whereas sedimentary rocks and alluvium are found to be the less thick and the most conductive. These results are of primary interest in view of the future set up of distributed hydrological models over the Cévennes-Vivarais region.

KEY WORDS: hydraulic soil properties, streamflow recession, deep soil horizons, soil databases, Boussinesq equation, storage capacity, regionalisation 


\section{INTRODUCTION}

For flood risk assessment and water resources management, the knowledge of parameters that control water transfers at the catchment scale is essential. Especially, soil depth, vertical and lateral saturated hydraulic conductivity are known to be of primary importance in catchment responses. At the regional scale, hydrologists have to deal with the lack of available data over large areas, leading to low confidence in the parameters values. The PUB (Prediction in Ungauged Basins) initiative (Sivapalan et al., 2003), launched ten years ago, aimed at tackling the lack of data on poorly gauged or ungauged catchments, by identifying relationships between landscapes and hydrologic responses. Many studies tried to classify catchments on the basis of their hydrologic similarity in observed response (e.g. Sawicz et al., 2011), or to regionalise calibrated model parameters on the basis of spatial proximity and/or catchment physical similarity (e.g. Merz and Blöschl, 2004; Nester et al., 2011). As advocated by McDonnell and Woods (2004) and Wagener et al. (2007), catchment classification is recognized to be a key challenge in hydrological science.

Among the various tools developed to evaluate and classify catchment responses, the analysis of streamflow recessions has been widely used. Streamflow recession provides useful insights in catchment hydrological behaviours, and also gives quantitative information on the hydrological properties required for setting-up distributed hydrological models. For more than one hundred years, authors have studied recession curves on the basis of various techniques and underlying theories, as reviewed by Hall (1968) and Tallaksen (1995).

In this study, we consider the general framework introduced by Brutsaert and Nieber (1977), who did not make any assumption on the linearity of the streamflow recession curve. Brutsaert and Nieber (1977) looked at the recession rate $-d Q / d t$ as a function of $Q$, suggesting a power-law relationship. They linked this relationship with analytical solutions of the onedimensional Boussinesq equation (Boussinesq, 1877), which describes the evolution of a transient water table above an impermeable layer in a homogeneous hillslope. Brutsaert and Nieber (1977) extrapolated this theory from hillslope to the whole catchment scale, assuming that a catchment is composed of homogenous and identical hillslopes. They focused on two non-linear power-law solutions of the Boussinesq equation: one valid at short time 
(Polubarinova-Kochina, 1962), and one valid at long time (Boussinesq, 1904). They graphically adjusted lower envelopes of the relationship $-d Q / d t$ vs. $Q$ for several eastern American catchments, arguing that considering lower envelopes of the scatter plot would avoid the effect of evapotranspiration on the recession rate. Many authors used methodologies directly derived from Brutsaert and Nieber (1977) to estimate catchment-scale hydraulic properties of aquifers using streamflow recession analysis (Zecharias and Brutsaert, 1988; Troch et al., 1993; Brutsaert, 1994; Szilagyi et al., 1998; Brutsaert and Lopez, 1998; Mendoza et al., 2003; Dewandel et al., 2003; Rupp and Selker, 2006b). Most of them used the same early and late solutions. Brutsaert (1994) generalised the early solution by considering a nonnull slope. Rupp and Selker (2006b) made an exhaustive review of all the possible solutions of the Boussinesq equation, for both horizontal and sloping aquifers. Furthermore, they derived empirical numerical solutions of the Boussinesq equation in the case of steep aquifers and aquifers presenting hydraulic conductivities varying with depth (power law decay). Huyck et al. (2005) developed a physically-based filter to extract baseflow from streamflow measurements series, on the basis of the Boussinesq equation. They proved the reliability of the method, through a comparison to other classical baseflow separation techniques.

Among all the parameters that streamflow recession analysis can help to determine, Szilagyi et al. (1998), Brutsaert and Lopez (1998) and Mendoza et al. (2003) focused their analysis on the lateral saturated hydraulic conductivity $k$ and the depth of impermeable layer $D$. These two parameters are probably the most difficult to estimate at the catchment scale, while they are of primary importance for water transfers. For hillslopes where subsurface flows are essentially driven by topography (high slopes), Rupp and Selker (2006b) obtained numerical results that differed from analytical solutions of the Boussinesq equation used in previous studies (Zecharias and Brutsaert, 1988; Brutsaert, 1994). Harman et al. (2009) led to the same conclusion for catchments composed of heterogeneous hillslopes (variability of slopes, lengths, soil depths and conductivities) and thus agreed with findings made by Clark et al. (2009), who showed that the response of a combination of parallel linear reservoirs could explain the non-linear behaviour observed at the catchment-scale on the Panola Mountain Research Watershed, Georgia, USA. Recently, Pauwels and Troch (2010) extended the Brutsaert-Nieber recession analysis methodology to a more general case: considering that some of the required assumptions of the theory (initially fully saturated aquifer, no recharge) 
are not often valid, they derived a new analytical solution valid at short-times, consistent with more realistic conditions.

Streamflow recession analysis techniques can be very helpful to better estimate parameters values used in hydrological models. Especially, soil and aquifer hydraulic properties are difficult to measure, but play a major role in the hydrological response of the catchments. In the Cévennes-Vivarais region, on which this study focuses, some models have been used at the regional scale, to simulate past flash-flood events (Saulnier and LeLay, 2009; Manus et al., 2009; Anquetin et al., 2010; Braud et al., 2010; Roux et al., 2011; Garambois et al., 2013). These works pointed out the need for accurate soil properties (especially storage capacity and hydraulic conductivity) to properly set up hydrological models: for example, Braud et al. (2010) discussed the importance of correctly estimating the water deficit of soils before a flood event; Anquetin et al. (2010) showed that the impact of uncertainties on soil properties on simulated discharges can be of the same order of magnitude as the impact of uncertainties in rainfall estimation at the catchment scale.

This study presents two methodologies aiming at providing information on soil properties at the catchment-scale over the Cévennes-Vivarais region. The first one (DSCI: Drainable Storage Capacity Index) is an indicator of the catchment-scale storage capacity, based on the direct comparison between discharge and precipitation series. The second methodology is the streamflow recession analysis as proposed by Brutsaert and Nieber (1977). The main objective is to derive soil storage capacities and hydraulic conductivity from streamflow recession characteristics on a sample of headwater catchments, and to compare the obtained results to existing information. In a regional modelling perspective, we propose to link the estimated parameters with landscape properties (especially geology), in order to further set up distributed hydrological models. To our knowledge, it is one of the first time that the Brutsaert and Nieber (1977) analysis is used in such a regional context and to address open key questions associated with the PUB initiative. This paper first describes the studied region (section 2) and the detailed methodology (section 3) built to derive the soil parameters of interest. In section 4, the results, compared to previous studies, point out the relationship between the geology of the catchments and the derived soil properties. Finally, conclusions 
are made, and perspectives on the future use of these parameters in regional distributed hydrological models are exposed. 


\section{CASE STUDY}

\subsection{General context}

The Cévennes-Vivarais region, located in the south-eastern part of the Massif Central (Figure 1), is prone to severe flash-floods, mostly occurring during the fall season. Extreme flood events have long been studied and analysed. They constitute the research topic of the Cévennes-Vivarais Mediterranean Hydro-meteorological Observatory ${ }^{1}$ (Boudevillain et al., 2011) and are the main issue of the $\mathrm{HyMeX}^{2}$ (Hydrological cycle in Mediterranean Experiment) research program (Ducrocq et al., 2010; Drobinski et al., 2013). The CévennesVivarais region is subject to various climatic conditions, arising from the topography (elevation ranges from sea level to $1699 \mathrm{~m}$ at Mont-Lozère). The geology is also diversified within the area: sedimentary rocks (limestone and marls) are dominant in the plain region, whereas metamorphic schist and crystalline hard-rocks (granite and gneiss) constitute the principal geology on reliefs (Figure 1). Historical flash-floods events have been documented within the observatory, using historical data documentation and through post-event peak discharge estimates (Gaume et al., 2003) that are used to evaluate the capacity of rainfallrunoff models to reproduce the response of catchments, either for prediction purposes (Versini et al., 2010; Vincendon et al., 2010) or for process understanding (Manus et al., 2009; Saulnier and LeLay, 2009; Anquetin et al., 2010; Braud et al., 2010; Tramblay et al., 2010; Roux et al., 2011).

\subsection{Available data}

Streamflow observations are publically available data, extracted from the French national hydrological database ${ }^{3}$, except data on the Valescure catchment, provided by the UMR $\mathrm{ESPACE}^{4}$ research laboratory. Discharge data are available at variable time step: water stage is recorded for each relative variation of at least $5 \%$. As consequence, time step can be small (up to a few seconds) for rapid variations (e.g. during floods). When no significant change is observed, the time step is much larger (up to several hours). Discharge data derives from

\footnotetext{
${ }^{1}$ http://www.ohmcv.fr/

${ }^{2}$ http://www.hymex.org/

${ }^{3} \mathrm{http}: / / w w w . h y d r o . e a u f r a n c e . f r /$

${ }^{4}$ Unité Mixte de Recherche «Étude des Structures, des Processus d'Adaptation et des Changements de l'Espace » http://www.umrespace.org/
} 
water stage measurements through rating curves, which can be associated with non-negligible uncertainties, especially during low flow periods. To plot $-d Q / d t$ vs. $Q$, the time steps are used as they are, without interpolation. We thus expect to avoid the artefacts described by Rupp and Selker (2006a).

Rainfall and snowfall data are extracted from the SAFRAN meteorological reanalyses (Vidal et al., 2010). In SAFRAN, meteorological variables (including solid and liquid precipitation) are available at an hourly time step, on a regular $8 \mathrm{~km}$ x $8 \mathrm{~km}$ grid cell, from 1958 until now.

Soil moisture measurements are also used in this work. Different kinds of soil moisture devices have been deployed for various research projects on 14 sites, at different depths, covering various types of vegetation and soil types. Some TDR (Time Domain Reflectometry) devices (IMKO TRIME®-PICO IPH/T3), provided by the UMR ESPACE laboratory, were installed on the Valescure catchment (Tramblay et al., 2010). Other devices are ThetaProbe ML2X (Delta-T Devices): some were installed by the HydroSciences Montpellier ${ }^{1}$ laboratory on 8 sites, measuring soil moisture at two or three different depths (between $-20 \mathrm{~cm}$ and -120 $\mathrm{cm}$ ). Others are part of the SMOSMANIA network (Soil Moisture Observing System Meteorological Automatic Network Integrated Application ${ }^{2}$ ) (Albergel et al., 2008), and provide water content measurements at $-5 \mathrm{~cm},-10 \mathrm{~cm},-20 \mathrm{~cm}$ and $-30 \mathrm{~cm}$. The locations of soil moisture measurements are shown by yellow triangles in Figure 1.

Information on soils is provided by two soil databases: the BD-sols Ardèche and the BD-sols Languedoc-Roussillon (Robbez-Masson et al., 2000). They were established on the basis of soil surveys performed since the 90's for agronomic purposes. These databases offer detailed geographical information on texture, structure, and thicknesses of soil horizons. Commonly, pedotransfer functions (e.g. Rawls and Brakensiek, 1985) are used by modellers to derive the needed hydraulic parameters from soil texture and structure, in order to get water retention and hydraulic conductivity curves (e.g. Manus et al., 2009).

\subsection{Critical analysis of the BD-sols databases}

\footnotetext{
${ }^{1}$ http://www.hydrosciences.org/

${ }^{2}$ http://www.cnrm.meteo.fr/spip.php?article251
} 
Although the BD-sols databases offer valuable and necessary information for hydrological models, their major weakness is that they were produced for agronomic uses, as highlighted by Braud et al. (2010). As a consequence, there is an evident lack of information concerning soil horizons that have no interest for agronomy: thickness of $\mathrm{C}$ type pedological horizon (corresponding to weathered rock layers situated above the bedrock, as shown in the example of pedologic profile in Figure 2) is almost never documented, whereas thickness of upper horizons (O, A, B, see Figure 2) always is. Subsequently, distributed hydrological models that rely on these databases (Manus et al., 2009; Anquetin et al., 2010; Braud et al., 2010; Roux et $a l ., 2011)$ do not account for storage capacities of weathered rock layers.

However, several analyses of historical flood events (Cosandey, 1994) and some recent modelling studies (Tramblay et al., 2010, 2011; Roux et al., 2011; Garambois et al., 2013) showed that effective soil storage capacities on Cévennes-Vivarais catchments often largely exceed the storage capacities of the upper soil layers described in the BD-sols. The total storage capacity for each catchment is calculated on the basis of the BD-sols information as follows:

$$
S_{\text {tot }}=\frac{\sum_{j=1}^{N_{\text {soil unit }}} A^{j}\left[\sum_{i=1}^{N_{\text {horizon }}}\left(\theta_{S_{i}^{j}}^{j}-\theta_{r_{i}^{j}}^{j}\right) H_{i}^{j}\right]}{\sum_{j=1}^{N_{\text {soil unit }}} A^{j}}
$$

where $S_{t o t}$ is the catchment-averaged total storage capacity $(\mathrm{m}), H$ is the thickness of the described soil horizons $(\mathrm{m}), \theta_{s}$ and $\theta_{r}$ are the saturated and residual water content $\left(\mathrm{m}^{3} \cdot \mathrm{m}^{-3}\right)$, respectively, of the described soil horizons, $N_{\text {soil unit }}$ is the number of mapped soil units that compose the catchment, $A$ is the area of each soil unit $\left(\mathrm{m}^{2}\right)$, and $N_{\text {horizon }}$ is the number of described soil horizons in each soil unit. $S_{\text {tot }}$ is the result of two successive operations: i) a sum of the storage capacities of all the horizons $\left(N_{\text {horizon }}\right)$ that compose a vertical soil profile; ii) a spatial average over all the soil units $\left(N_{\text {soil unit }}\right)$ of the catchment. $\theta_{s}$ and $\theta_{r}$ are calculated from soil texture and structure for each horizon, according to Rawls and Brakensiek (1985). Table 1 presents a comparison between $S_{t o t}$, as calculated with equation (1), and estimations derived from flood events surveys or from modelling studies. Table 1 clearly highlights the general underestimation (from $-33 \%$ to $-87 \%$ ) of soils storage capacities calculated with the use of parameters given in the BD-sols.

This general underestimation is consistent with the known limitations of the BD-sols, which do not usually document deep soil layers (horizons $\mathrm{C}$ and deeper). On this basis, we therefore 
assume that the non-documented weathered rock horizons are responsible of a substantial part of the catchment storage capacity. This paper describes and compares two methods for the estimation of this storage capacity.

\subsection{Catchment selection}

The two analyses are applied to several Mediterranean gauged catchments, located in the Cevennes-Vivarais region (south-east of France). Selection criteria for the catchments are:

1. Availability of a long enough discharge measurements series (at least five recent years), for hydrological representativeness considerations;

2. The catchment sample must cover the range of landscapes and geological entities present in the Cevennes-Vivarais region;

3. Small headwater catchments (smaller than $100 \mathrm{~km}^{2}$ ) are privileged, in order to ensure a maximal representativeness towards a given landscape, and to be homogeneous in terms of geomorphology. This is a key selection criteria, since several recent studies (Rupp and Selker, 2006b; Clark et al., 2009; Harman et al., 2009) highlighted possible artefacts in the estimated hydraulic parameters of the Brutsaert-Nieber methodology, due to the natural variability of the hillslopes (in terms of hydraulic conductivity, slope) within the catchments.

Table 2 summarises the main features of the twenty-three selected catchments. All the catchments are independent, except two of them (Latte, \#15 and Cloutasses, \#6) which are part of a larger one (Tarn at Pont-de-Montvert, \#19). The location of the selected catchments is given in Figure 1, superimposed on the geologic map. 


\section{METHODOLOGY}

In this section, we develop two approaches to assess catchment-scale properties by means of streamflow data analysis. We first define an indicator of the storage capacity of catchments (the Drainable Storage Capacity Index: DSCI). Then, we present the methodology derived from Brutsaert and Nieber (1977), used here to estimate depth to impermeable bedrock and saturated hydraulic conductivity of the aquifer.

\subsection{Definition of the Drainable Storage Capacity Index (DSCI)}

DSCI is based on a simple comparison between discharge and precipitation series. It relies on the quantification of delayed flow volumes. Soil is seen as a reservoir, with a total storage capacity $S_{t o t}$, which slowly releases water into streams. By quantifying the volume of water that has been released with a certain delay after rainfall, and by comparing this volume to the volume of rainfall, it is possible to get a lower bound estimate of $S_{t o t}$ at the catchment scale. The methodology used to calculate DSCI is described hereafter, and is illustrated in Figure 3 for one catchment:

1. As we only consider water that has transited through the ground, we first need to avoid overland flow. This is done by neglecting streamflow occurring during and immediately after a rainfall event, for the duration $T$. We thus consider $Q^{*}(t)$, which derives from $Q(t)$ as follows:

$$
\begin{aligned}
& \text { if } P(t)>0 \text { for } t_{1}<t \leq t_{2} \\
& \text { then } Q^{*}(t)=0 \text { for } t_{1}<t \leq\left(t_{2}+T\right) \text { else } Q^{*}(t)=Q(t)
\end{aligned}
$$

where $t_{1}$ and $t_{2}$ are the beginning and ending time of rainfall, respectively. $T$ is specifically calculated for each catchment on the basis of a $25 \mathrm{~m}$-resolution Digital Elevation Model (DEM) analysis. Distance to outlet is computed for each DEM cell, using a D8 algorithm (O'Callaghan and Mark, 1984). $T$ is considered equal to the maximum distance to outlet divided by a constant value of surface runoff velocity (Saulnier and LeLay, 2009; Vincendon et al., 2010), here chosen equal to $0.5 \mathrm{~m} . \mathrm{s}^{-1}$.

2. Snowfall periods, and the 15 days that immediately follow snowfall, are ignored, to avoid artefacts due to snow melt. Snow depth at the ground is unknown (SAFRAN only distinguishes between liquid and solid precipitations). Nevertheless, we assume that under 
the Mediterranean climatic conditions, periods during which snow accumulates on the ground do not usually exceed 15 days. In Figure 3a, an example of the Tarn discharge series at Pont-de-Monvert (\#19) is presented as well as the associated $Q^{*}(t)$ kept for the selected periods.

3. For each catchment, the cumulated precipitation curve $P(t)(\mathrm{mm})$ is subtracted to the cumulated streamflow curve $Q^{*}(t)(\mathrm{mm})$ to give $I(t)$ :

$$
I(t)=\sum_{t}\left(Q^{*}(t)-P(t)\right)
$$

The trend of $I(t)$ generally decreases, since on average, rainfall amounts are higher than streamflow volumes. But this curve presents some local increases, namely called "delayed flow periods": they correspond to periods during which there is more flow out of the catchment than rain (release of stored water). In Fig.3b, the resulting $I(t)$ curve is plotted for the previous example ;

4. For each delayed flow period, the maximum delayed flow volume (in $\mathrm{mm}$ ) is defined as the amplitude of the local increase. This is an indication on how much water has been stored by this catchment before being released. Figure $3 \mathrm{c}$ gives an example of a $112 \mathrm{~mm}$ delayed flow volume observed in 2001 for the Tarn catchment (\#15).

5. DSCI is the maximum value $(\mathrm{mm})$ of all the delayed flow volumes identified over the whole observation period: DSCI therefore provides an estimation of the storage capacity of each catchment.

As mentioned above, DSCI is a lower-bound estimate of the storage capacity, for at least four reasons:

- Evapotranspiration is not taken into account. In a similar water balance approach, Sayama et al. (2011) accounted for evapotranspiration, assuming potential evapotranspiration equal to actual evapotranspiration. We choose not to make such an assumption in this study, because we consider it not realistic under the Mediterranean climatic conditions;

- Overland flow is avoided by ignoring the first hours of streamflow after rainfall. As a consequence, a part a subsurface flow is unfortunately ignored; 
- Since DSCI is the maximum of the observed delayed flow volumes, its value depends on the length of the archive: the longer the streamflow series is, the more DSCI will be representative of the effective storage capacity of a catchment;

- DSCI is an indicator on the drainable water storage, not on the total water storage, which includes drainable water and water linked to solid particles by capillarity forces.

Nevertheless, DSCI is a relatively simple method to assess catchment-scale storage capacities since it only requires discharge and precipitation series. Furthermore, this method does not imply to make uncertain assumptions on the physical properties or on the geometry of the catchments.

\subsection{Analysis of streamflow recessions}

\subsubsection{Theory}

A methodology similar to the one first described by Brutsaert and Nieber (1977) is used here. This methodology has been reused by many authors since its first description (Troch et al., 1993; Brutsaert, 1994; Szilagyi et al., 1998; Brutsaert and Lopez, 1998; Mendoza et al., 2003; Dewandel et al., 2003; Rupp and Selker, 2006b). This approach assumes a power-law relationship between the recession rate $-d Q / d t\left(\mathrm{~m}^{3} \cdot \mathrm{s}^{-1} \cdot \mathrm{day}^{-1}\right)$ and the discharge $Q\left(\mathrm{~m}^{3} . \mathrm{s}^{-1}\right)$ :

$$
-\frac{d Q}{d t}=a Q^{b}
$$

where $\mathrm{a}$ and $\mathrm{b}$ are constant. Brutsaert and Nieber (1977) linked this relationship with analytical solutions of the one-dimensional Boussinesq equation (Boussinesq, 1904) that describes the evolution of a transient water table above an impermeable layer in a homogeneous hillslope, under the well-described Dupuit approximation:

$$
\varphi \frac{\partial h}{\partial t}=\cos \beta \frac{\partial}{\partial x}\left(k h \frac{\partial h}{\partial x}\right)+\sin \beta \frac{\partial}{\partial x}(k h)
$$

where $h$ is the height of the water table $(\mathrm{m}), t$ is the time (s), $x$ is the longitudinal coordinate along the hillslope (m), $\beta$ is the slope of the terrain (degrees), $\varphi$ is the drainable porosity of the aquifer $\left(\mathrm{m}^{3} \cdot \mathrm{m}^{-3}\right)$ and $k$ the horizontal saturated hydraulic conductivity of the aquifer $\left(\mathrm{m} \cdot \mathrm{s}^{-1}\right)$. Here, two non-linear analytical solutions of equation (5) are considered:

1. The first one is valid at short time (Polubarinova-Kochina, 1962), and is adapted to sloping aquifers by Brutsaert (1994): 


$$
b=3 ; a=\frac{1.133}{k \varphi D^{3} L^{2} \cos \beta}
$$

where $D$ is the depth to the impermeable bedrock (m) and $L$ is the length of surface streams that drain the aquifer $(\mathrm{m})$;

2. The second one is valid at long time (Boussinesq, 1904):

$$
b=\frac{3}{2} ; a=\frac{4.804 k^{1 / 2} L}{\varphi A^{3 / 2}}
$$

where $A$ is the area covered by the aquifer $\left(\mathrm{m}^{3}\right)$.

The recession rate $-d Q / d t$ is plotted vs. the discharge $Q$ for each catchment, using logarithmic scales. Two examples of $-d Q / d t$ vs. $Q$ plots are shown in Figure 4 . As proposed by Brutsaert and Nieber (1977), we consider the lower envelopes of data, with slopes corresponding to the early and late solutions (i.e. equal to 3 and 3/2), respectively. The adjustment of the lower envelope is done automatically by the use of an iterative procedure stopped when $98 \%$ of the points lie above the envelope curve. Troch et al. (1993) and Mendoza et al. (2003) used a similar approach with a lower threshold (90\% and 95\%). Based on sensitivity tests, Troch et al. (1993) concluded that the value of the threshold criterion could not change significantly the obtained results.

$D(\mathrm{~m})$ and $k\left(\mathrm{~m} \cdot \mathrm{s}^{-1}\right)$ are the two physical parameters we wish to estimate through this analysis. Once the intercept values $a$ of the two envelope curves are known, $k$ is extracted from the long-time solution (7), and introduced into the short-time solution (6) to determine $D$. As Mendoza et al. (2003) mentioned, drainable porosity $\varphi$ is also an unknown parameter. Nevertheless, we consider that its natural range of variability (for $\mathrm{C}$ horizon and fractured bedrock) is narrower than the range of variability of saturated hydraulic conductivity for example. In this study, two values are used $\left(0.05 \mathrm{~m}^{3} \cdot \mathrm{m}^{-3}\right.$ and $\left.0.1 \mathrm{~m}^{3} \cdot \mathrm{m}^{-3}\right)$ to get an estimation of the uncertainty associated with $\varphi$.

The other parameters of the Boussinesq solutions are estimated as follows: $L$ is the mapped length of the river network provided by the French national geographic institute ${ }^{1}$. We choose to take into account the intermittency of the river network for its estimation. In equation (6) (i.e. the short time solution), $L$ accounts for both intermittent and permanent streams, whereas

\footnotetext{
${ }^{1}$ http://www.ign.fr/
} 
for the long time solution (i.e. equation (7)), we only consider the length of permanent streams. The parameter $A$ is assumed equal to the total area of the catchment. $\beta$ is the median slope of the catchment, derived from a 25m resolution Digital Elevation Model. These values are given in Table 2 as regard as the catchments.

\subsubsection{Extraction of recession periods}

To apply the Brutsaert and Nieber (1977) methodology, recession periods must first be isolated. We chose to consider periods during which discharge values decreases with time. The retained criteria to extract recession periods are:

- Discharge must decrease on average over 6 moving time steps. This value arises from sensitivity tests during which recession periods were "validated" visually;

- As done for the DSCI calculation and in order to avoid snow melt, snowfall periods and the 15 days that immediately follow snowfall, are ignored ;

- The minimum number of discharge measurements that compose a recession period is fixed to 10. This is done to ensure a certain consistency in the observations that are used;

\subsubsection{Determination of saturation duration in upper soil horizon through soil moisture} observations

As described in the introduction, this work aims at complementing the partial description provided by the BD-sols soil databases. Considering a typical pedologic profile (Figure 2), one needs to distinguish between horizons that are completely described in the BD-sols, namely $\mathrm{O}, \mathrm{A}$ and $\mathrm{B}$ type horizons, and deeper horizons that are not documented ( $\mathrm{C}$ and $\mathrm{R}$ type horizons), for which we seek to get estimates of thickness and hydraulic conductivity. Since the objective is to get information on the weathered rock deep horizons, we need to ensure that the analysed streamflow recession only results from the contribution of these deep layers. The recession analysis used in this study assumes (for the short-time solution) an initial saturation of the layers that contribute to the streamflow. This assumption is later discussed. In order not to consider contributions of the upper soil horizons ( $\mathrm{O}, \mathrm{A}$ and $\mathrm{B}$ types), we analyse the saturation duration of these soil horizons. 
We assume that upper soil layers contribute to lateral subsurface flows only for a limited time $T_{s}$ after a rainfall event. We also assume that lateral subsurface flows are the consequence of a transient saturation of these soil layers. Based on those hypotheses, soil water content measurements are used to determine the average duration $T_{s}$ of saturation in the upper soil horizons, which depends on the soil type. Particular attention is paid to deep measurements (60 cm and more) if available. As illustrated in Figure 5, two typical behaviours are identified. For the majority of soil types, it is found that saturation almost never happens (Figure 5b): soil water content measurements exhibit brief peaks that do not exceed a few hours. Poor draining soils (typically clay and silty-clay soils) reach saturation after rainfall events and remain saturated during several days (Figure 5a). On the basis of this analysis, average durations $T_{s}$ of saturation are estimated according to the nature of soil. These estimates are given in Table 3.

To avoid subsurface flow generated by saturated upper soil, recession between $t=0$ and $t=T s$ is systematically ignored in streamflow recession analyses. An example of the resulting extracted recession periods is shown in Figure 6, for the Auzonnet (\#4) catchment. 


\section{RESULTS}

\subsection{DSCI}

In Figure 7, DSCI is calculated for each catchment and compared with the spatially-averaged drainable storage capacity $S_{\text {drain }}$, calculated using the BD-sols database information as follows:

$$
S_{\text {drain }}=\frac{\sum_{j=1}^{N_{\text {soil unit }}} A^{j}\left[\sum_{i=1}^{N_{\text {horizon }}}\left(\theta_{S_{i}^{j}}-\theta_{f_{i}^{j}}^{j}\right) H_{i}^{j}\right]}{\sum_{j=1}^{N_{\text {soil unit }}} A^{j}}
$$

Equation (8) only differs from equation (1) by the term $\theta_{f}$, which is the soil water content at field capacity $\left(\mathrm{m}^{3} \cdot \mathrm{m}^{-3}\right)$. The difference $\theta_{S}-\theta_{f}$ is the drainable porosity.

Figure 7 highlights the significant gap between calculated DSCI values and the estimations of soils storage capacities based on the soil database information, which are commonly used in distributed hydrological models. For granite, gneiss and schist catchments, DSCI values always exceed BD-sols estimates, except for one catchment (Volane, \#23). Inversely, the indicator is always lower than the BD-sols estimates for sedimentary and alluvial catchments, except one (Lez, \#16). One should notice that in the cases where the BD-sols estimates are larger than the computed indicator, it does not mean that the BD-sols storage capacities are over-estimated. The comparison can only detect under-estimations, because DSCI is a lowerbound estimate, as mentioned in section 3 .

Figure 7 also points out differences between geologic entities. Catchments on crystalline rocks (granite and gneiss) globally present the highest values of DSCI: most of them (7 among 9) show delayed flow volumes larger than $140 \mathrm{~mm}$. The distinction between other geologies (schist, sedimentary rocks and alluvium) is not straightforward, even if catchments on schist seem to present intermediate values of DSCI (from 50 to $150 \mathrm{~mm}$ ), while catchments on sedimentary rocks and alluvium are associated with lower DSCI values on average. Note that the storage capacities $S_{\text {drain }}$ estimated with the parameters of the BD-sols do not present any tendency with the dominant geology.

\subsection{Assessment of $D$ and $k$ using streamflow recession analysis}


Two examples of $-d Q / d t$ vs. $Q$ plots with adjusted lower envelopes corresponding to $b=3$ (short time solution) and $b=3 / 2$ (long time solution) are shown in Figure 4. The resulting couples $(D, k)$ for the selected catchments are plotted in Figure 8. In this figure, the vertical and horizontal error bars refer to the uncertainty in the chosen value of drainable porosity (from $0.05 \mathrm{~m}^{3} \cdot \mathrm{m}^{-3}$ to $0.1 \mathrm{~m}^{3} \cdot \mathrm{m}^{-3}$ ).

Figure 8 reveals a major separation between the different geologies. The application of the Boussinesq theory in our analysis shows that crystalline catchments (in red) are those with the largest values of weathered rock horizon thicknesses (between $7 \mathrm{~m}$ and $20 \mathrm{~m}$ on average), followed by catchments located on schist (from $2 \mathrm{~m}$ to $5 \mathrm{~m}$ on average). Estimated active thicknesses of weathered rock horizons on sedimentary rocks and alluvium are the lowest, ranging from $0 \mathrm{~m}$ to $2 \mathrm{~m}$. The trend for hydraulic conductivities is opposite: sedimentary rocks and alluvium present the highest values of $k\left(30000 \mathrm{~mm} \cdot \mathrm{h}^{-1}\right.$ to $300000 \mathrm{~mm} \cdot \mathrm{h}^{-1}$ on average); then the weathered schist horizons ( $k$ ranging from $10000 \mathrm{~mm} \cdot \mathrm{h}^{-1}$ to $30000 \mathrm{~mm} \cdot \mathrm{h}^{-1}$ on average) and the weathered crystalline layers ( $k$ ranging from $250 \mathrm{~mm} \cdot \mathrm{h}^{-1}$ to $4500 \mathrm{~mm} \cdot \mathrm{h}^{-1}$ on average). Such values of lateral saturated hydraulic conductivity may appear unusual, since they exceed by several orders of magnitude the commonly measured vertical saturated hydraulic conductivity of soils (e.g. through the use of infiltrometers). However, values of catchment-scale lateral saturated hydraulic conductivities larger than $10000 \mathrm{~mm} \cdot \mathrm{h}^{-1}$ are frequently estimated in modelling studies, via model calibration (Saulnier and LeLay, 2009; Vincendon et al., 2010; Roux et al., 2011; Garambois et al., 2013). The sensitivity of the results to the value of the drainable porosity seems relatively limited, and it might not modify the hierarchy found between the geologic entities.

\subsection{Comparison of DSCI and storage capacities estimated with streamflow recession analysis}

Streamflow recession analysis provides estimates of the depth to impermeable layer $D(\mathrm{~m})$ (Figure 8) as a function of the chosen value of drainable porosity $\varphi\left(\mathrm{m}^{3} \cdot \mathrm{m}^{-3}\right)$. Multiplying $D$ by $\varphi$, we obtain an estimation of the drainable storage capacity of weathered rock horizons. To get the storage capacity of the whole soil profile the drainable storage capacity of uppersoil horizons, given by the BD-sols databases (8), is added. In Figure 9, this total drainable storage capacity is compared to DSCI. Vertical bars stand for the superposition of upper-soil and deep horizon drainable storage capacities. Upper-soil storage capacities do not notably vary with the geology type whereas deep layers reveal storage capacities that are highly 
dependent on the geology. On hard-rock crystalline catchments (gneiss and granite bedrock), the major part of storage is located in the deep horizon. For these catchments, upper-soil presents a drainable storage capacity lower than $200 \mathrm{~mm}$, but the whole storage capacity (upper + deep horizons) ranges from $600 \mathrm{~mm}$ to $1200 \mathrm{~mm}$. Catchments located on schist also present a storage capacity mainly localised in the deep horizon. These catchments are characterized with very little upper-soil storage capacity according to the BD-sols (lower than $100 \mathrm{~mm}$ ), although their total drainable storage capacity ranges from $200 \mathrm{~mm}$ to $400 \mathrm{~mm}$. For sedimentary and alluvial catchments, the storage capacity of the deep horizon is of the same order of magnitude as the storage capacity of the upper horizons.

DSCI (symbolized by black horizontal bars) presents lower values of storage capacity. The link between DSCI and the geology is approximately the same as previous results with particularly high values for catchments located on crystalline basement. Figure 9 brings out an evident consistency between the two methods. DSCI never exceeds the storage values obtained through recession analysis, which is concordant with the lower-bound estimate nature of DSCI, and proves the complementarity of the two methods. The non-perfect correlation between the results of the two methods is probably a consequence of one of the DSCI limitations: the catchments for which the gap between storage estimates and DSCI is the largest are catchments for which we disposed of the shortest streamflow archive (e.g. Valescure, \#20: 6 years; Volane, \#23: 5 years; Dardaillon, \#7: 3 years).

\section{DISCUSSION}

\subsection{Regarding the methods}

Large amounts of uncertainties still remain on the soil water storage capacity, in particular of deeper horizons. Our results show that, when conjointly used, the two methods presented here provide robust conclusions. Namely, the DSCI method, built on very few hypotheses and the Brutsaert-Nieber analysis, which needs more hypotheses, are found complementary.

One strong hypothesis concerns the homogeneous nature of the hillslopes of the catchments. Having this point in mind, the selection of the catchments was done to minimise possible variability of some physical descriptors (e.g. geology, land use, soil types, topography) and 
therefore to reduce artefacts associated with the heterogeneity in the parameter estimations (Rupp and Selker, 2006b; Clark et al., 2009; Harman et al., 2009).

Another hypothesis associated with the theory underlying the analytical short-time solution (Polubarinova-Kochina, 1962) used in the Brutsaert-Nieber methodology is the assumption of an initial full saturation of the aquifer. The theory considers an aquifer with an effective depth $p D$ to impermeable bedrock, where $D$ is the depth of porous rock, and $p$ is a constant factor (corresponding to the fraction of $D$ that effectively contributes to the base flow) chosen between 1 (full vertical saturation) and 0 (no saturation). Brutsaert and Nieber (1977), proposed to use a constant value $p=0.3465$, and many authors make the same assumption. Pauwels and Troch (2010) developed a new methodology, more in accordance with the hypotheses of the Boussinesq's theory of recessions. Instead of looking at the recession part (and thus making the hypothesis of an aquifer initially fully saturated), Pauwels and Troch (2010) analysed the rising limb of the base-flow hydrograph, assuming no recharge after a long rainless period. Their methodology provides more accurate estimations of aquifer hydraulic properties, even if the authors recognise that "if one is interested in knowing catchment-averaged hydraulic parameters, a traditional base flow recession analysis will lead to results that will give an indication of the order of magnitude of these parameters". Since the governing motivation of our work is the regional aspect of the estimation, and the link with the physical descriptors (geology) of the catchments, we state that applying the traditional streamflow recession analysis to our data is relevant towards this purpose.

\subsection{Choice of the parameter values and influence on the results}

The Brutsaert-Nieber analysis implies to fix some parameter values $(L, A, \beta, \varphi)$. The sensitivity of the results to value of the porosity $\varphi$ has been assessed, as shown in Figure 8. As many authors (Troch et al., 1993; Szilagyi et al., 1998; Brutsaert and Lopez, 1998; Mendoza et al., 2003), we consider $A$ equal to the catchment area. A sensitivity analysis to the proportion of $A$ that effectively contributes to the streamflow was made (not shown). It reveals a strong impact on the estimated values of $k$ and $D$. In the case where only $20 \%$ of the catchment contributes to the recession flow, the estimated values of $\mathrm{k}$ range from $2 \mathrm{~mm} . \mathrm{h}^{-1}$ (granite) to $2000 \mathrm{~mm} \cdot \mathrm{h}^{-1}$ (alluvium); this is two order of magnitude below estimations given in Figure 8, when considering a contribution of the whole catchment area. Accordingly, the estimation of $D$ is about 4.5 times higher. However, in absence of more detailed information 
on the spatial extent of the contributing aquifers in the selected catchments we consider that the total catchment area contributes to the recession flow, even if we keep in mind that this can lead to an overestimation of $k$ (and accordingly to an underestimation of $D$ ).

We also distinguish the length of permanent and temporary streams in the long time and short time solutions. To our knowledge, this has never been done before. This choice is possible here because the information on the length of permanent streams is available. To assess the impact of this choice on the results, we also performed a comparison between the results presented in Figure 8 and the results obtained without making such a distinction. It reveals a very good correlation between the two methods, both for $D\left(\mathrm{R}^{2}=0.84\right)$ and $k\left(\mathrm{R}^{2}=0.79\right)$. Not accounting for distinct types of streams would result in seven times lower values of $k$ on average, and increased values of D by $50 \%$ on average, but would not modify the hierarchy showed in Figure 8.

\subsection{Geology signature on the estimated $k$ and $D$}

The discussion on the estimated values of $k$ and $D$ is guided by the geologic entity:

\section{Crystalline rocks (granite and gneiss)}

The calculated thickness of weathered rock horizons is the largest among all the geologic entities. Nevertheless, as compared to the literature (e.g. Wyns et al., 2004; Dewandel et al., 2006; Lachassagne et al., 2011), these values remain within the natural range of variability. All of these previous studies reported thickness of saprolite (defined as the upper layer of hard-rock alteration profile, lying upon a fractured rock layer) of about $10 \mathrm{~m}$ to $20 \mathrm{~m}$. Saprolite layers are considered as porous media, with drainable porosities ranging from $0.02 \mathrm{~m}^{3} . \mathrm{m}^{-3}$ to $0.1 \mathrm{~m}^{3} \cdot \mathrm{m}^{-3}$ (Dewandel et al., 2006).

Dewandel et al. (2006) estimated hydraulic conductivity in saprolite layers and fractured layers of a granitic Indian catchment and did a review of similar previous works. They found that the geometrical mean of the hydraulic conductivity estimated in literature (essentially through pumping tests) is equal to $2 \times 10^{-6} \mathrm{~m} \cdot \mathrm{s}^{-1}$ (i.e. $7.2 \mathrm{~mm} \cdot \mathrm{h}^{-1}$ ), with a range of variability between $7 \times 10^{-8} \mathrm{~m} \cdot \mathrm{s}^{-1}\left(0.2 \mathrm{~mm} \cdot \mathrm{h}^{-1}\right)$ and $4 \times 10^{-5} \mathrm{~m} \cdot \mathrm{s}^{-1}\left(144 \mathrm{~mm} \cdot \mathrm{h}^{-1}\right)$. Furthermore, the fissured bedrock layer located directly below the saprolite layer is found to be more conductive (due to fracturation), with hydraulic conductivities ranging from $3 \times 10^{-7} \mathrm{~m} \cdot \mathrm{s}^{-1}\left(1 \mathrm{~mm} \cdot \mathrm{h}^{-1}\right)$ to $10^{-3} \mathrm{~m} \cdot \mathrm{s}^{-1}$ 
(3 $\left.600 \mathrm{~mm} \cdot \mathrm{h}^{-1}\right)$, with a geometric mean equal to $9 \times 10^{-6} \mathrm{~m} \cdot \mathrm{s}^{-1}\left(32 \mathrm{~mm} \cdot \mathrm{h}^{-1}\right)$. These values are on average lower than those estimated in the present study. However, the present values $(250-$ $4500 \mathrm{~mm} \cdot \mathrm{h}^{-1}$ ) are not out of the range of the values found in literature, even if they stand close to the upper bound.

\section{Schists}

Studies focused on the hydraulic properties of schist horizons are not as common as for crystalline rocks. Therefore, the values of $k$ and $D$ parameters cannot be compared to any from the literature. We may explain the fact that estimated hydraulic conductivities are larger than on hard-rocks by the anisotropic structure of schist layers, as shown by Martin et al. (2004), who studied the impact of the relation between slope direction and schist planar structure direction on streamflow generation of a Mediterranean catchment. They highlighted the hydrological consequences of preferential sloping direction of schist layers. This may be a possible explanation for the high values of $k$ obtained here.

\section{Sedimentary rocks and alluvium}

Sedimentary rock catchments as well as catchments on alluvial material are found to be those having the shallowest and the most conductive weathered horizons. The physical reasons of these results may lie on the presence of karst in the underground of limestone catchments. Karstic systems are common in the sedimentary area of the Cévennes-Vivarais region. Karsts are known to be associated to very high groundwater flow velocity, up to several hundreds of $\mathrm{m} . \mathrm{h}^{-1}$ (Bakalowicz, 2005), due to the existence of large drains. One of the selected catchments (Lez at Montferrier-sur-Lez, \#16) is known to be karstic, and has been widely studied (Fleury et al., 2009). However, the other catchments are supposed not to be karstic (or only partially, such as the Vidourle at Sauve, \#21). Yet, all of the sedimentary rock catchments behave globally in the same way, according to the results shown in Figure 8. This could mean that all of these catchments present fissured rock horizons that are conductive enough to result in high values of hydraulic conductivities at the catchment scale. This is a major issue for the future setting-up of distributed hydrological models over this area. 


\section{CONCLUSION}

This work highlights the signature of geology on the hydrological behaviour of catchments. Based on the Boussinesq's theory, we analyse streamflow recessions for twenty-three Mediterranean headwater catchments. This allows us determining catchment-scale storage capacities and lateral hydraulic conductivities of deep soil horizons, which are generally poorly known and not considered in distributed hydrological models. We also assess the overall storage capacity of catchments through the use of another indicator, named the Drainable Storage Capacity Index (DSCI), which relies on a simple comparison between precipitation and discharge series. In both cases, the catchment properties are found to be closely related to the dominant geology. In particular, crystalline hard rock catchments seem to present very thick and moderately conductive weathered rock horizons, while sedimentary rock catchments are found to have shallow but very conductive weathered rock horizons. These results represent a major step forward to the knowledge of deep soil horizons properties, which are known to play an important role in water transfers. This study also proves the reliability of experimental data analyses for better understanding hydrological processes, and its complementarity with modelling works. Particularly, it confirms the meaningfulness of streamflow recessions, which can provide major insights on the large-scale subsurface properties of catchments, hard to measure by traditional means.

To go further in the knowledge of the effective processes that governs the water transfers in Mediterranean regions, we recommend: i) to extrapolate the obtained results to ungauged catchments, based on the established link between geology and deep layers properties; ii) to use the estimated properties in the distributed hydrological models that will later be set-up over the Cévennes-Vivarais region and thus to assess the effect on the simulated response of catchments; iii) to define experimental ways of verifying the validity of the results presented here, especially for lateral hydraulic conductivities, that are found to be several orders of magnitude larger than the values traditionally considered in rainfall-runoff modelling.

\section{ACKNOWLEDGEMENTS}

This work is part of the FloodScale project, which is funded by the French National Research Agency (ANR) under contract $\mathrm{n}^{\circ}$ ANR 2011 BS56 027, which contributes to the HyMeX program. The authors acknowledge Christophe Bouvier and Pascal Brunet, from 
HydroSciences Montpellier (UMR 5569), and Jean-François Didon-Lescot from ESPACE (UMR 7300) for supplying the soil moisture data and the Valescure catchment discharges. 


\section{LEGENDS}

\section{Figure 1}

Location of the selected catchments and soil moisture measurements, and geology (from BDsols Ardèche and Languedoc-Roussillon) of the Cevennes-Vivarais region.

\section{Figure 2}

Typical pedologic profile, after Kang \& Tripathi (1992) and level of description in the Cevennes-Vivarais BD-sols soil databases.

\section{Table 1}

Comparison of several catchment-scale storage capacities estimated in the literature with storage capacities estimated with the BD-sols soil databases by the use of equation (1).

\section{Table 2}

Main physical characteristics of the selected catchments and temporal windows of discharge measurements.

\section{Figure 3}

Illustration of the methodology used to extract delayed flow periods to compute DSCI index. Here is an example for the Tarn catchment (\#19, $67 \mathrm{~km}^{2}$ ), between 2001-09-01 and 2002-0901. (a) Time evolution of precipitation and discharge (discharge given on a logarithmic scale). "Considered discharge $Q^{*}(t)$ " refers to discharge measurements occurring i) late enough after a precipitation event to avoid overland flow (equation 5.2) ii) at least 15 days after a snowfall event. (b) Time evolution of $\mathrm{I}(\mathrm{t})$ (equation 5.3). Delayed flow periods (in red) are thus identified when cumulated discharge is larger than precipitation. (c) Time evolution of "delayed flow periods". For this example, the largest delayed flow volume is equal to 112 $\mathrm{mm}$.

\section{Figure 4}

Examples of $-\mathrm{dQ} / \mathrm{dt}$ vs. Q logarithmic plots for two catchments: (a) Ardèche in Meyras (\#2, $99 \mathrm{~km}^{2}$ ) and (b) Salaison in Mauguio $\left(\# 18,51 \mathrm{~km}^{2}\right.$ ) with adjusted lower envelope curves of slope $b=3$ and $b=3 / 2$.

\section{Table 3}

Results of the analysis of saturation durations $T_{\mathrm{s}}$ on 17 water content measurement sites. The range of observed $T_{s}$ for each soil is presented, as well as the retained value of $T_{s}$ that will effectively be ignored at the beginning of streamflow recessions analysis (not to account for upper soil contribution).

\section{Figure 5}

Temporal patterns of measured soil water content in two distinct soil types: (a) clay-loam soil on marls at Brouzet-les-Quissac, and (b) sandy loamy soil on granite at Valescure. Rainfall rate is plotted as grey bars.

\section{Figure 6}

Streamflow recession periods extracted between 2000-09-01 and 2001-09-01 in the Auzonnet catchment $\left(\# 4,49 \mathrm{~km}^{2}\right)$. Catchment-averaged precipitation is displayed in blue on the inverted $\mathrm{y}$-axis. Discharge series is shown in grey in logarithmic scale. The selected recession periods 
appear in red, and the first five days of recession that are ignored according to the analysis of saturation duration in upper soils are coloured in black.

\section{Figure 7}

Ranked values of calculated DSCI for each catchment (coloured triangles) compared to drainable storage capacities estimated with the BD-sols databases (black horizontal bars). Colours correspond to the dominant geology of catchments.

\section{Figure 8}

Depth to bedrock $\mathrm{D}$ and lateral hydraulic conductivity $\mathrm{k}$ calculated using streamflow recession analysis. The confidence intervals result from the uncertainty in the value of drainable porosity (between $0.05 \mathrm{~m}^{3} \cdot \mathrm{m}^{-3}$ and $0.1 \mathrm{~m}^{3} \cdot \mathrm{m}^{-3}$ ).

\section{Figure 9}

Total drainable storage capacities estimated for each catchment. Distinction is made between storage capacities of upper soil horizons (calculated using the BD-sols databases information) and storage capacities of deep horizons (estimated using streamflow recession analysis). The storage capacity is compared to the DSCI indicator. 


\section{REFERENCES}

Albergel C, Rüdiger C, Pellarin T, Calvet JC, Fritz N, Froissard F, Suquia D, Petitpa A, Piguet B, Martin E. 2008. From near-surface to root-zone soil moisture using an exponential filter: an assessment of the method based on in-situ observations and model simulations. Hydrology and Earth System Sciences 12 : 1323-1337. DOI: 10.5194/hess-12-1323-2008

Anquetin S, Braud I, Vannier O, Viallet P, Boudevillain B, Creutin J-D, Manus C. 2010. Sensitivity of the hydrological response to the variability of rainfall fields and soils for the Gard 2002 flash-flood event. Journal of Hydrology 394: 134-147. DOI: 10.1016/j.jhydrol.2010.07.002

Bakalowicz M. 2005. Karst groundwater: a challenge for new resources. Hydrogeology Journal 13 : 148-160.

Boudevillain B, Delrieu G, Galabertier B, Bonnifait L, Bouilloud L, Kirstetter P-E, Mosini ML. 2011. The Cévennes-Vivarais Mediterranean Hydrometeorological Observatory database. Water Resources Research 47 : W07701. DOI: 10.1029/2010WR010353

Boussinesq J. 1877. Essai sur la théorie des eaux courantes. In french. Mémoires à l'Académie des Sciences de l'Institut National de France 1

Boussinesq J. 1904. Recherches théoriques sur l'écoulement des nappes d'eau infiltrées dans le sol et sur le débit des sources. In french. Journal de Mathématiques Pures et appliquées $\mathbf{1 0}$ : 5-78.

Braud I, Roux H, Anquetin S, Maubourguet M-M, Manus C, Viallet P, Dartus D. 2010. The use of distributed hydrological models for the Gard 2002 flash flood event: Analysis of associated hydrological processes. Journal of Hydrology 394 : 162-181. DOI: 10.1016/j.jhydrol.2010.03.033

Brutsaert W. 1994. The unit response of groundwater outflow from a hillslope. Water Resources Research 30: 2759-2763.

Brutsaert W, Lopez JP. 1998. Basin-scale geohydrologic drought flow features of riparian aquifers in the Southern Great Plains. Water Resources Research 34: 233-240.

Brutsaert W, Nieber JL. 1977. Regionalized drought flow hydrographs from a mature glaciated plateau. Water Resources Research 13: 637-643.

Clark MP, Rupp DE, Woods RA, Tromp-van Meerveld HJ, Peters NE, Freer JE. 2009. Consistency between hydrological models and field observations: linking processes at the hillslope scale to hydrological responses at the watershed scale. Hydrological Processes 23 : 311-319. DOI: 10.1002/hyp.7154Cosandey C. 1994. Formation des crues "cévenoles" dans les bassins élémentaires du mont Lozère. In french. Revue des sciences de l'eau 7: 377-393.

Cosandey C, Didon-Lescot J-F. 1990. Etude des crues cévenoles: conditions d'apparition dans un petit bassin forestier sur le versant sud du Mont Lozère, France. In french. IAHS Publications : Regionalization in hydrology 
Dewandel B, Lachassagne P, Bakalowicz M, Weng P, Al-Malki A. 2003. Evaluation of aquifer thickness by analysing recession hydrographs. Application to the Oman ophiolite hard-rock aquifer. Journal of Hydrology 274: 248-269.

Dewandel B, Lachassagne P, Wyns R, Maréchal JC, Krishnamurthy NS. 2006. A generalized 3-D geological and hydrogeological conceptual model of granite aquifers controlled by single or multiphase weathering. Journal of Hydrology 330: 260-284.

Drobinski, V. Ducrocq, P. Alpert, E. Anagnostou, K. Béranger, M. Borga, I. Braud, A. Chanzy, S. Davolio, G. Delrieu, C. Estournel, N. Filali Boubrahmi, J. Font, V. Grubisic, S. Gualdi, V. Homar, B. Ivancan-Picek, C. Kottmeier, V. Kotroni, K. Lagouvardos, P. Lionello, M.C. Llasat, W. Ludwig, C. Lutoff, A. Mariotti, E. Richard( R. Romero, R. Rotunno, O. Roussot, I. Ruin, S. Somot, I. Taupier-Letage, J. Tintore, R. Uijlenhoet, H. Wernli, 2013. HyMeX, a 10-year multidisciplinary program on the Mediterranean water cycle, Bulletin of the American Meteorological Society, submitted.

Ducrocq V et al. 2010. HyMeX Science Plan [online] Available from: http://www.hymex.org/public/documents/HyMeX_Science_Plan.pdf

Fleury P, Ladouche B, Conroux Y, Jourde H, Dörfliger N. 2009. Modelling the hydrologic functions of a karst aquifer under active water management - The Lez spring. Journal of Hydrology 365 : 235-243.

Garambois PA, Roux H, Larnier K, Castaings W, Dartus D. 2013. Characterization of process-oriented hydrologic model behavior with temporal sensitivity analysis for flash floods in Mediterranean catchments. Hydrology and Earth System Sciences 17 : 2305-2322. DOI: 10.5194/hess-17-2305-2013

Gaume E, Livet M, Desbordes M. 2003. Study of the hydrological processes during the Avene river extraordinary flood (south of France): 6-7 October 1997. Physics and Chemistry of the Earth, Parts A/B/C 28: 263-267. DOI: 10.1016/S1474-7065(03)00036-6

Hall FR. 1968. Base-Flow Recessions: A Review. Water Resources Research 4: 973-983.

Harman CJ, Sivapalan M, Kumar P. 2009. Power law catchment-scale recessions arising from heterogeneous linear small-scale dynamics. Water Resources Research 45 [online] Available from: http://dx.doi.org/10.1029/2008WR007392

Huyck AAO, Pauwels VRN, Verhoest NEC. 2005. A base flow separation algorithm based on the linearized Boussinesq equation for complex hillslopes. Water Resources Research 41. DOI: $10.1029 / 2004$ WR003789

Kang B., Tripathi B. 1992. Technical paper 1: Soil classification and characterization. In Alley Farming Training Manual ,. The AFNETA - Alley Farming Research Network for Africa;

Lachassagne P, Wyns R, Dewandel B. 2011. The fracture permeability of Hard Rock Aquifers is due neither to tectonics, nor to unloading, but to weathering processes. Terra Nova 23: 145-161. DOI: 10.1111/j.1365-3121.2011.00998.x

Manus C, Anquetin S, Braud I, Vandervaere J-P, Creutin J-D, Viallet P, Gaume E. 2009. A modeling approach to assess the hydrological response of small mediterranean catchments to 
the variability of soil characteristics in a context of extreme events. Hydrology and Earth System Sciences 13: 79-97. DOI: 10.5194/hess-13-79-2009

Martin F, Martin C, Lavabre J, Folton N. 2004. Fonctionnement hydrologique des bassins versants de roches métamorphiques : exemple du bassin versant des Maurets (massif des Maures, Var, France). In french. Études de Géographie Physique 31: 39-69.

McDonnell JJ, Woods R. 2004. On the need for catchment classification. Journal of Hydrology 299: 2-3.

Mendoza GF, Steenhuis TS, Walter MT, Parlange J-Y. 2003. Estimating basin-wide hydraulic parameters of a semi-arid mountainous watershed by recession-flow analysis. Journal of Hydrology 279: 57-69.

Merz R, Blöschl G. 2004. Regionalisation of catchment model parameters. Journal of Hydrology 287: 95-123.

Nester T, Kirnbauer R, Gutknecht D, Blöschl G. 2011. Climate and catchment controls on the performance of regional flood simulations. Journal of Hydrology 402: 340-356.

O'Callaghan J, Mark D. 1984. The Extraction of Drainage Networks from Digital Elevation Data. Computer Vision Graphics and Image Processing 28: 323-344. DOI: 10.1016/S0734189X(84)80011-0

Pauwels VRN, Troch PA. 2010. Estimation of aquifer lower layer hydraulic conductivity values through base flow hydrograph rising limb analysis. Water Resources Research 46:. DOI: $10.1029 / 2009$ WR008255

Polubarinova-Kochina P. 1962. Theory of Ground Water Movement. Princeton University Press: Princeton, NJ.

Rawls WJ, Brakensiek DL. 1985. Prediction of Soil Water Properties for Hydrologic Modeling: 293-299. In E.B. Jones and T.J. Ward (eds.). Watershed Management in the Eighties. ASCE.

Robbez-Masson JM, Barthes JP, Bornand M, Falipou P, Legros JP. 2000. Bases de données pédologiques et systèmes d'informations géographiques. L'exemple de la région LanguedocRoussillon. In french. Forêt Méditerranéenne 1: 88-98.

Roux H, Labat D, Garambois P-A, Maubourguet M-M, Chorda J, Dartus D. 2011. A physically-based parsimonious hydrological model for flash floods in Mediterranean catchments. Natural Hazards and Earth System Science 11: 2567-2582. DOI: 10.5194/nhess11-2567-2011

Rupp DE, Selker JS. 2006a. Information, artifacts, and noise in dQ/dt-Q recession analysis. Advances in Water Resources 29: 154-160.

Rupp DE, Selker JS. 2006b. On the use of the Boussinesq equation for interpreting recession hydrographs from sloping aquifers. Water Resources Research 42 [online] Available from: http://dx.doi.org/10.1029/2006WR005080 
Saulnier G-M, LeLay M. 2009. Sensitivity of flash-flood simulations on the volume, the intensity, and the localization of rainfall in the Cévennes-Vivarais region (France). Water Resources Research 45 [online] Available from: http://dx.doi.org/10.1029/2008WR006906

Sawicz K, Wagener T, Sivapalan M, Troch PA, Carrillo G. 2011. Catchment classification: empirical analysis of hydrologic similarity based on catchment function in the eastern USA. Hydrology and Earth System Sciences 15: 2895-2911. DOI: http://dx.doi.org/10.5194/hess15-2895-2011

Sayama T, McDonnell JJ, Dhakal A, Sullivan K. 2011. How much water can a watershed store? Hydrological Processes 25: 3899-3908. DOI: 10.1002/hyp.8288

Sivapalan M et al. 2003. IAHS Decade on Predictions in Ungauged Basins (PUB), 20032012: Shaping an exciting future for the hydrological sciences. Hydrological Sciences Journal 48: $857-880$.

Szilagyi J, Parlange MB, Albertson JD. 1998. Recession flow analysis for aquifer parameter determination. Water Resources Research 34: 1851-1857.

Tallaksen LM. 1995. A review of baseflow recession analysis. Journal of Hydrology 165: 349-370.

Tramblay Y, Bouvier C, Ayral P-A, Marchandise A. 2011. Impact of rainfall spatial distribution on rainfall-runoff modelling efficiency and initial soil moisture conditions estimation. Natural Hazards and Earth System Science 11: 157-170. DOI: 10.5194/nhess-11$157-2011$

Tramblay Y, Bouvier C, Martin C, Didon-Lescot J-F, Todorovik D, Domergue J-M. 2010. Assessment of initial soil moisture conditions for event-based rainfall-runoff modelling. Journal of Hydrology 387: 176-187. DOI: 10.1016/j.jhydrol.2010.04.006

Troch PA, De Troch FP, Brutsaert W. 1993. Effective water table depth to describe initial conditions prior to storm rainfall in humid regions. Water Resources Research 29: 427-434.

Versini P-A, Gaume E, Andrieu H. 2010. Application of a distributed hydrological model to the design of a road inundation warning system for flash flood prone areas. Natural Hazards and Earth System Science 10: 805-817. DOI: 10.5194/nhess-10-805-2010

Vidal J-P, Martin E, Franchisteguy L, Baillon M, Soubeyroux J-M. 2010. A 50-year highresolution atmospheric reanalysis over France with the Safran system. International Journal of Climatology 30 : 1627-1644. DOI: 10.1002/joc.2003

Vincendon B, Ducrocq V, Saulnier G-M, Bouilloud L, Chancibault K, Habets F, Noilhan J. 2010. Benefit of coupling the ISBA land surface model with a TOPMODEL hydrological model version dedicated to Mediterranean flash-floods. Journal of Hydrology 394: 256-266. DOI: 10.1016/j.jhydrol.2010.04.012

Wagener T, Sivapalan M, Troch P, Woods R. 2007. Catchment Classification and Hydrologic Similarity. Geography Compass 1: 901-931. DOI: 10.1111/j.1749-8198.2007.00039.x

Wyns R, Baltassat J, Lachassagne P, Legchenko A, Vairon J, Mathieu F. 2004. Application of proton magnetic resonance soundings to groundwater reserve mapping in weathered basement 
rocks (Brittany, France). Bulletin de la société géologique de France 175: 21-34. DOI: 10.2113/175.1.21\

Zecharias YB, Brutsaert W. 1988. Recession characteristics of groundwater outflow and base flow from mountainous watersheds. Water Resour. Res. 24 : 1651-1658 


\section{TABLES}

\begin{tabular}{|c|c|c|c|c|c|c|c|c|}
\hline & Latte & Cloutasses & Valescure & Beaume & \multicolumn{3}{|c|}{ Gardon d'Anduze } & Avène \\
\hline Area $\left(\mathrm{km}^{2}\right)$ & 0.195 & 0.81 & 3.9 & 205 & \multicolumn{3}{|c|}{543} & 58 \\
\hline Dominant geology & Granite & Granite & Granite & $\begin{array}{l}\text { Granite and } \\
\text { Gneiss }\end{array}$ & \multicolumn{3}{|c|}{ Schists } & Limestone \\
\hline $\begin{array}{l}\text { Bd-sols storage capacity } \\
(\mathrm{mm})\end{array}$ & 179 & 154 & 60 & 157 & \multicolumn{3}{|c|}{77} & 241 \\
\hline Study & $\begin{array}{l}\text { Cosandey, } \\
1994\end{array}$ & $\begin{array}{l}\text { Cosandey, } \\
1994\end{array}$ & $\begin{array}{c}\text { Tramblay et } \\
\text { al., } 2010\end{array}$ & $\begin{array}{l}\text { Garambois } \\
\text { et al., } 2013\end{array}$ & $\begin{array}{l}\text { Roux et al., } \\
\quad 2011\end{array}$ & $\begin{array}{c}\text { Tramblay et } \\
\text { al., } 2011\end{array}$ & $\begin{array}{l}\text { Garambois } \\
\text { et al., } 2013\end{array}$ & $\begin{array}{l}\text { Gaume et } \\
\text { al., } 2003\end{array}$ \\
\hline Nature of estimation & $\begin{array}{l}\text { Flood } \\
\text { analysis }\end{array}$ & $\begin{array}{l}\text { Flood } \\
\text { analysis }\end{array}$ & $\begin{array}{l}\text { Model } \\
\text { calibration }\end{array}$ & $\begin{array}{l}\text { Model } \\
\text { calibration }\end{array}$ & $\begin{array}{l}\text { Model } \\
\text { calibration }\end{array}$ & $\begin{array}{c}\text { Model } \\
\text { calibration }\end{array}$ & $\begin{array}{l}\text { Model } \\
\text { calibration }\end{array}$ & $\begin{array}{l}\text { Flood } \\
\text { analysis }\end{array}$ \\
\hline $\begin{array}{l}\text { Estimated storage capacity } \\
(\mathrm{mm})\end{array}$ & 270 & 230 & up to $420^{1}$ & 832 & 408 & up to $577^{1}$ & 354 & 200 \\
\hline Underestimation of $\mathrm{Bd}$-sols & $-34 \%$ & $-33 \%$ & $-86 \%$ & $-81 \%$ & $-81 \%$ & $-87 \%$ & $-78 \%$ & $+20 \%$ \\
\hline
\end{tabular}

'⿳亠口冋口灬 calibrated initial soil deficit : its value depends on the flood event

Table 1 Comparison of several catchment-scale storage capacities estimated in the literature with storage capacities estimated with the BDsols soil databases by the use of equation (1) 


\begin{tabular}{|c|c|c|c|c|c|c|c|c|c|}
\hline & & \multirow{2}{*}{$\begin{array}{c}\text { Area } A \\
\left(\mathrm{~km}^{2}\right)\end{array}$} & \multirow{2}{*}{$\begin{array}{l}\text { Median } \\
\text { slope } \beta \\
\left(^{\circ}\right)\end{array}$} & \multicolumn{2}{|c|}{ Length of streams $(\mathrm{km})$} & \multirow{2}{*}{$\begin{array}{c}\text { Highest } \\
\text { Strahler } \\
\text { order }^{1}\end{array}$} & \multirow{2}{*}{ Dominant geology } & \multirow{2}{*}{$\begin{array}{l}\text { Dominant soil } \\
\text { texture }\end{array}$} & \multirow{2}{*}{ Discharge measurement } \\
\hline & & & & $L_{\text {total }}$ & $L_{\text {permanent }}$ & & & & \\
\hline$\# 1$ & Alzon (Uzès) & 71.0 & 3.9 & 66.9 & 29.2 & 5 & Limestone & Loam & 1996-2008 \\
\hline$\# 2$ & Ardèche (Meyras) & 98.7 & 22.3 & 167.4 & 130.1 & 3 & Granite / Gneiss & Sandy loam & $1986-2010$ \\
\hline \#3 & Arre (Le Vigan) & 155.0 & 18.4 & 213.0 & 95.7 & 5 & Schist & Loam & $1995-2010$ \\
\hline \#4 & Auzonnet (Les Mages) & 49.0 & 14.9 & 66.6 & 17.6 & 3 & Limestone / marls & Clay loam & $1987-2006$ \\
\hline \#5 & Beaume (Rosières) & 200.0 & 21.0 & 340.0 & 259.2 & 5 & Schist & Sandy loam & $1999-2010$ \\
\hline \#6 & Cloutasses & 0.4 & 8.5 & 0.7 & 0.2 & 1 & Granite & Sandy loam & 1982-1995 \\
\hline$\# 7$ & Dardaillon (St-Just) & 36.4 & 2.1 & 48.5 & 20.3 & 3 & Alluvium & Clay loam & $1998-2000$ \\
\hline$\# 8$ & Dourbie (Dourbies) & 42.9 & 12.0 & 58.1 & 30.6 & 4 & Granite & Sandy loam & $1988-2010$ \\
\hline$\# 9$ & Gagnière (Gagnières) & 55.3 & 18.4 & 93.9 & 59.3 & 4 & Schist & Sandy loam & $1969-2010$ \\
\hline$\# 10$ & Gardon (Saumane) & 104.0 & 22.9 & 145.7 & 66.2 & 4 & Schist & Loam & 1984-1994 \\
\hline$\# 11$ & Gardon de Sainte-Croix & 47.0 & 18.4 & 50.8 & 20.6 & 3 & Schist & Loam & $1996-2010$ \\
\hline$\# 12$ & Gardon de Saint-Germain & 30.5 & 20.8 & 46.0 & 15.1 & 3 & Schist & Loam & $1980-2010$ \\
\hline$\# 13$ & Gardon de Saint-Martin & 30.5 & 21.2 & 46.2 & 17.5 & 3 & Schist & Loam & $1980-2010$ \\
\hline \#14 & Herault (Valleraugue) & 46.2 & 25.7 & 78.1 & 28.5 & 4 & Schist & Loam & $1968-1983$ \\
\hline \#15 & Latte & 0.2 & 10.5 & 0.4 & 0.1 & 1 & Granite & Sandy loam & 1981-1999 \\
\hline \#16 & Lez (Montferrier-sur-Lez) & 115.0 & 7.0 & 66.9 & 21.4 & 4 & Limestone & Clay & $1975-2010$ \\
\hline$\# 17$ & Rieumalet (Pont-de-Montvert) & 20.0 & 13.4 & 25.0 & 24.4 & 3 & Granite & Sandy loam & $1988-2010$ \\
\hline$\# 18$ & Salaison (Mauguio) & 50.8 & 3.5 & 60.0 & 16.9 & 3 & Limestone / marls & Clay & $1986-2010$ \\
\hline \#19 & Tarn (Pont-de-Monvert) & 67.0 & 11.1 & 92.4 & 82.1 & 4 & Granite & Sandy loam & $1987-2010$ \\
\hline \#20 & Valescure & 3.9 & 23.8 & 7.2 & 3.2 & 2 & Granite & Sandy loam & 2004-2010 \\
\hline \#21 & Vidourle (Sauve) & 190.0 & 10.1 & 281.7 & 55.3 & 5 & Limestone / marls & Clay & 1994-2006 \\
\hline \#22 & Vistre (Bernis) & 291.0 & 2.4 & 219.6 & 64.1 & 5 & Alluvium & Clay loam & $1978-2010$ \\
\hline$\# 23$ & Volane (Vals-les-Bains) & 109.0 & 20.8 & 148.6 & 77.6 & 4 & Granite / Gneiss & Sandy loam & 2006-2010 \\
\hline
\end{tabular}

\footnotetext{
${ }^{1}$ Strahler order calculated on the basis of a DEM-extracted stream network, with an extraction threshold of $0.5 \mathrm{~km}^{2}$
}

Table 2 Main physical characteristics of the selected catchments and temporal windows of discharge measurements 


\begin{tabular}{lcccc}
\hline & $\begin{array}{c}\text { Clay and } \\
\text { clay loam }\end{array}$ & Silt loam & Loam & $\begin{array}{c}\text { Sandy } \\
\text { loam }\end{array}$ \\
\hline $\begin{array}{l}\text { Range of observed } T s \text { (days) } \\
\begin{array}{l}\text { Proposed averaged duration of saturation } \\
T S \text { (days) }\end{array}\end{array}$ & $1-10$ & $0-1$ & 0 & 0 \\
\hline
\end{tabular}

Table 3 Results of the analysis of saturation durations $T_{s}$ on 17 water content measurement sites. The range of observed $T_{s}$ for each soil is presented, as well as the retained value of $T_{s}$ that will effectively be ignored at the beginning of streamflow recessions analysis (not to account for upper soil contribution). 


\section{FIGURES}

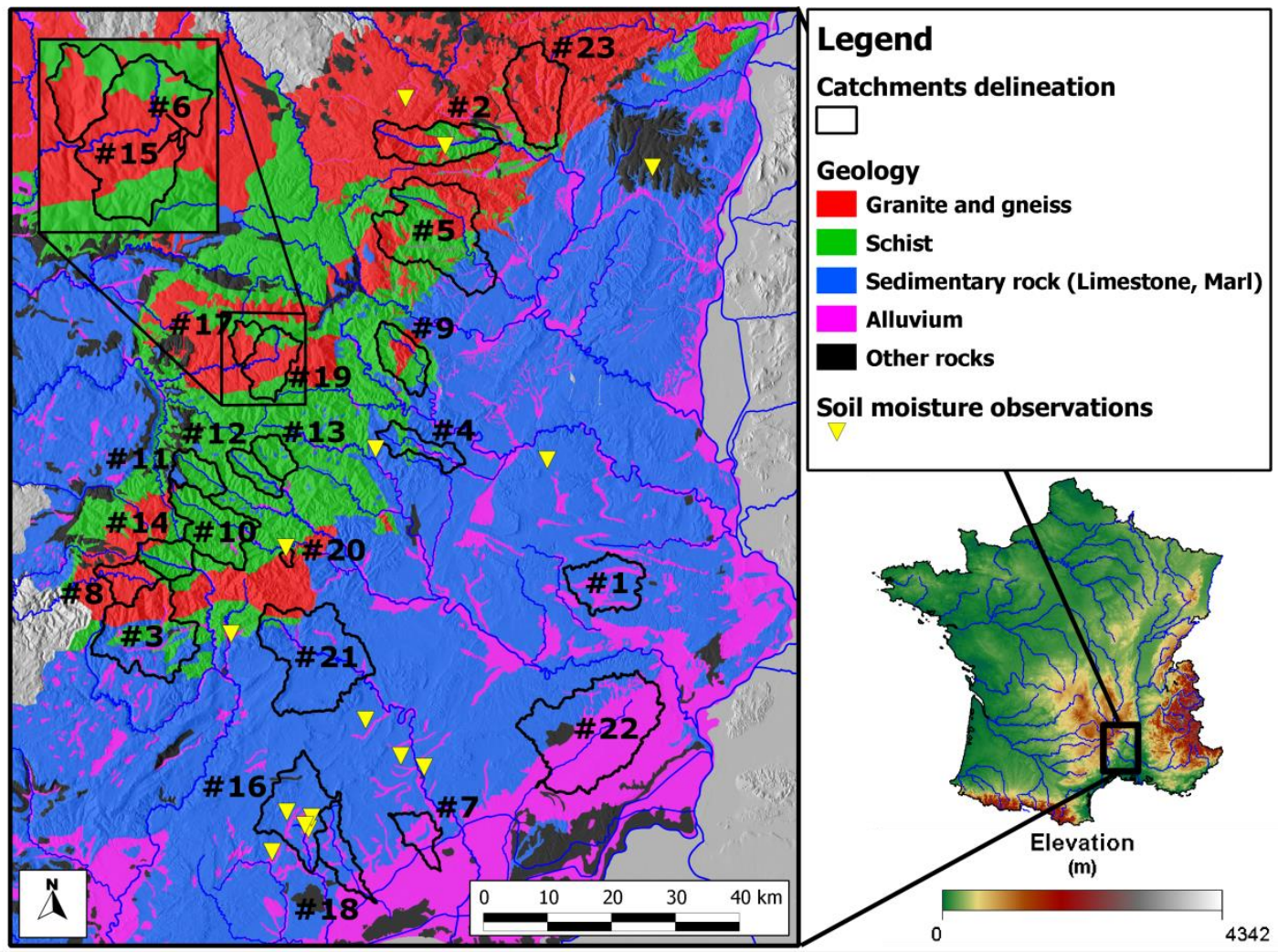

Figure 1 Location of the selected catchments and soil moisture measurements, and geology 
Well-described horizons in the BD-sols databases

Unknow thicknesses and hydrodynamic properties

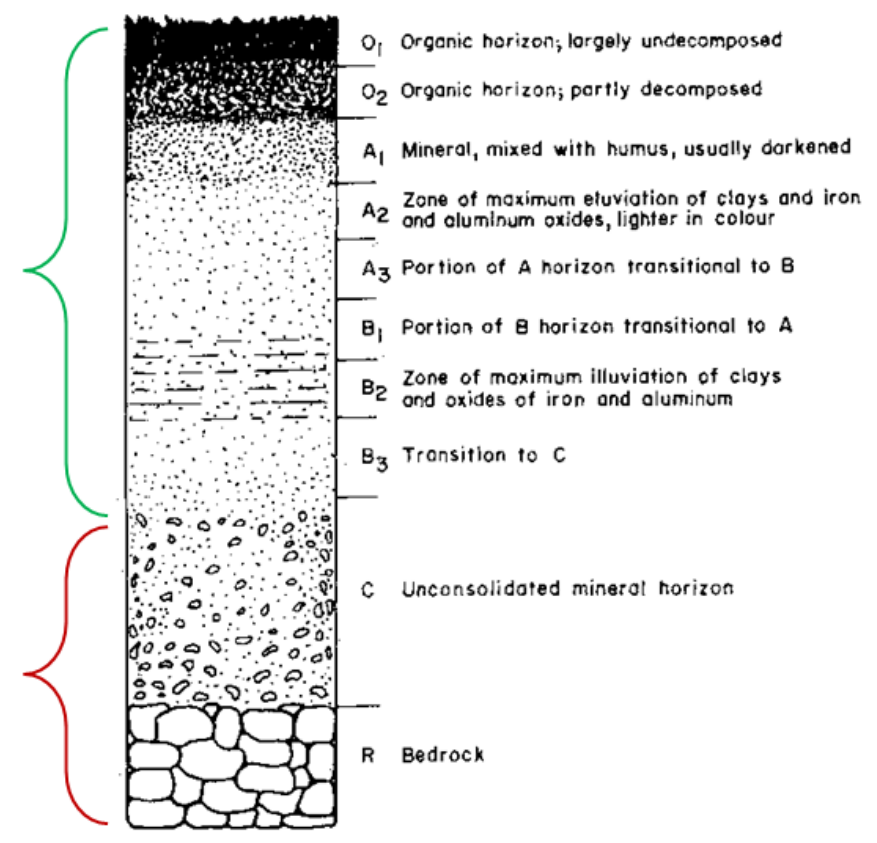

Figure 2 Typical pedologic profile, after Kang and Tripathi (1992) and level of description in the Cevennes-Vivarais BD-sols soil databases 

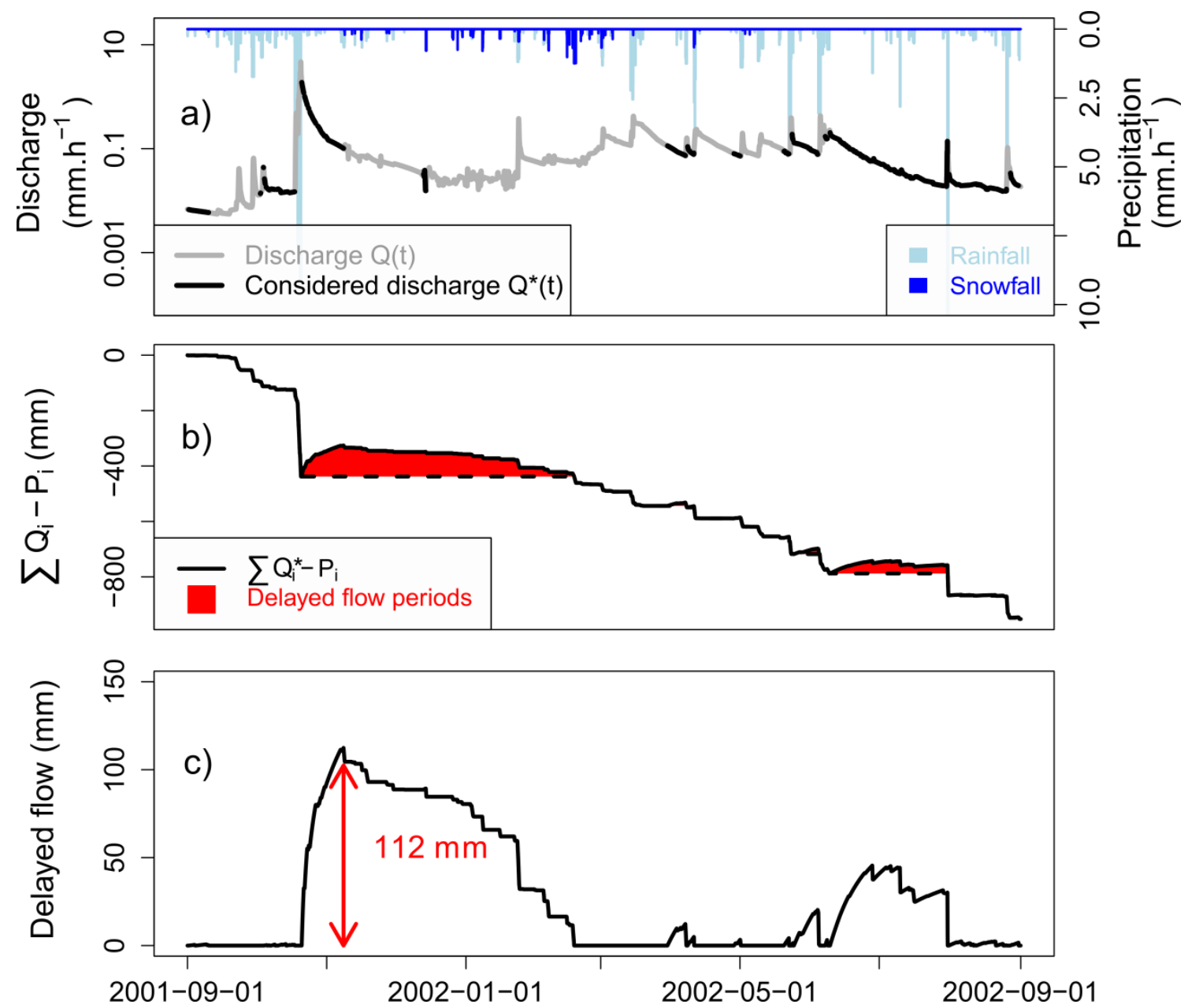

Figure 3 Illustration of the methodology used to extract delayed flow periods to compute DSCI index. Here is an example for the Tarn catchment (\#19, $\left.67 \mathrm{~km}^{2}\right)$, between 2001-09-01 and 2002-09-01.

a) Time evolution of precipitation and discharge (discharge given on a logarithmic scale). "Considered discharge $Q^{*}(t)$ " refers to discharge measurements occurring i) late enough after a precipitation event to avoid overland flow (2)(1) ii) at least 15 days after a snowfall event.

b) Time evolution of $I(t)$ (3). Delayed flow periods (in red) are thus identified when cumulated discharge is larger than precipitation.

c) Time evolution of "delayed flow periods". For this example, the largest delayed flow volume is equal to $112 \mathrm{~mm}$. 

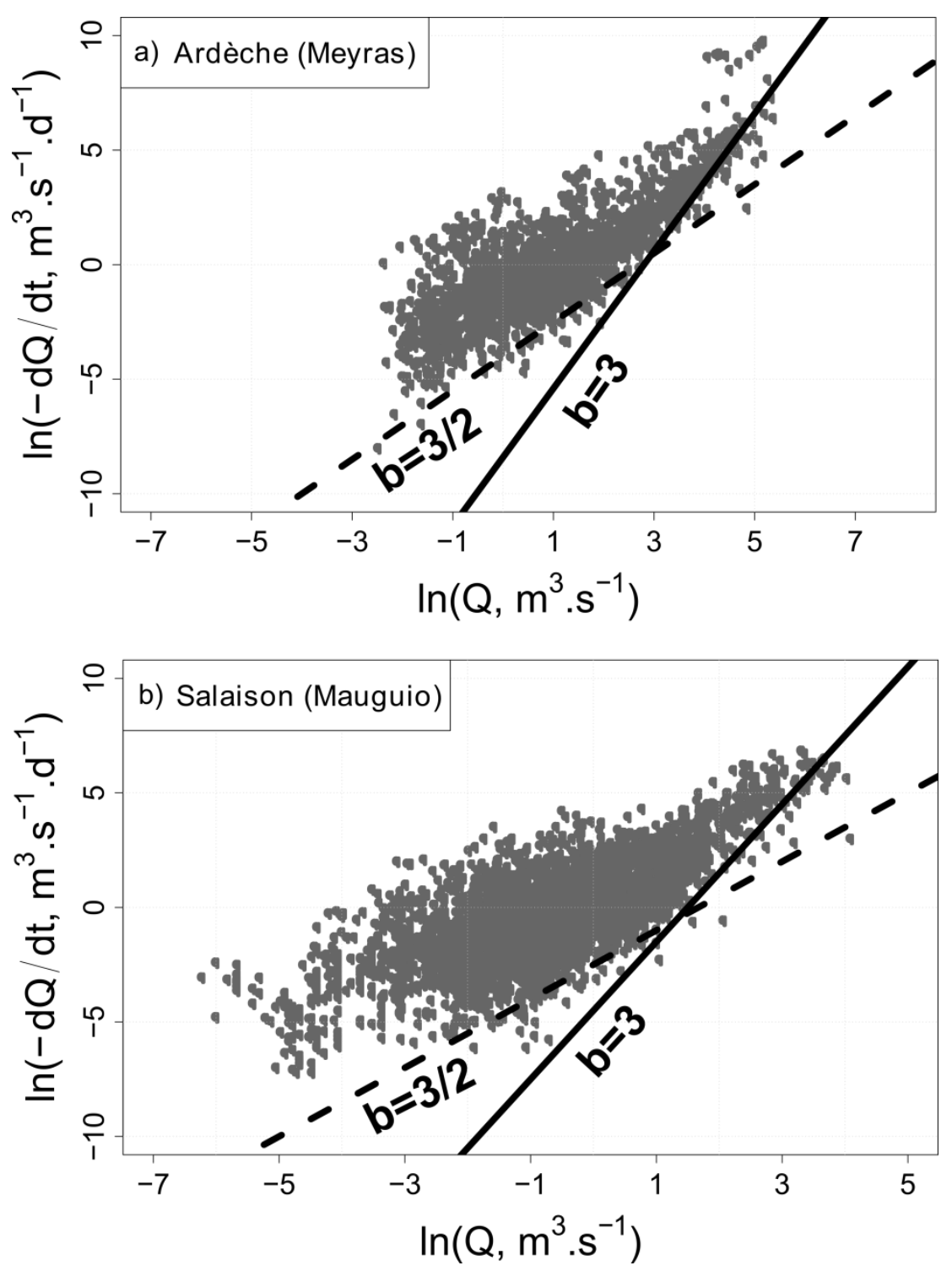

Figure 4 Examples of -dQ/dt vs. Q logarithmic plots for two catchments: Ardèche in Meyras(\#2, $\left.99 \mathrm{~km}^{2}\right)$ (a) and Salaison in Mauguio (\#18, $\left.51 \mathrm{~km}^{2}\right)($ b)with adjusted lower envelope curves of slope $b=3$ and $b=3 / 2$ 

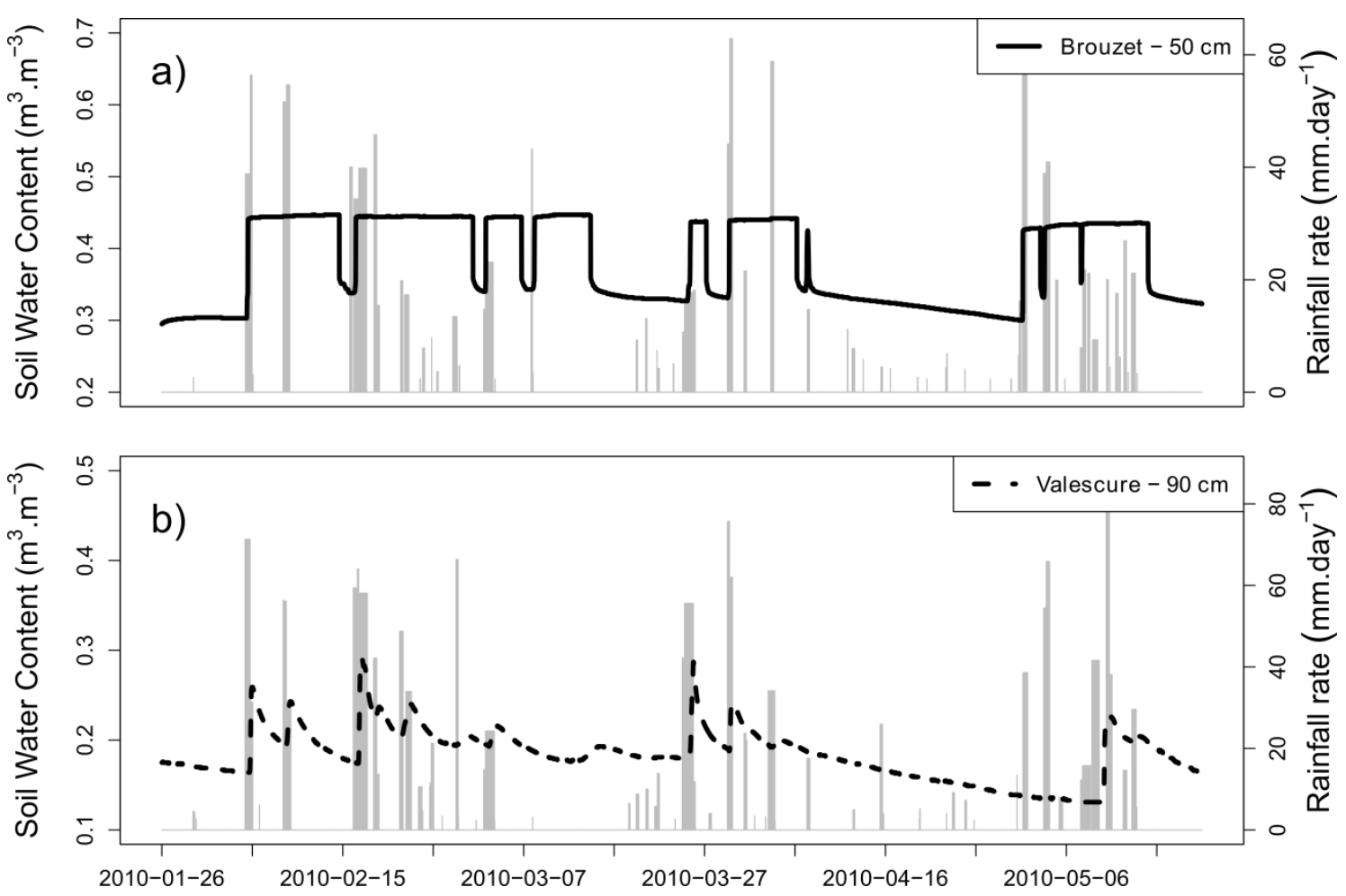

Figure 5 Temporal patterns of measured soil water content on two distinct soil types: clayloam soil on marls at Brouzet-les-Quissac (a), and sandy loamy soil on granite at Valescure (b). Rainfall rate is plotted as grey bars. 


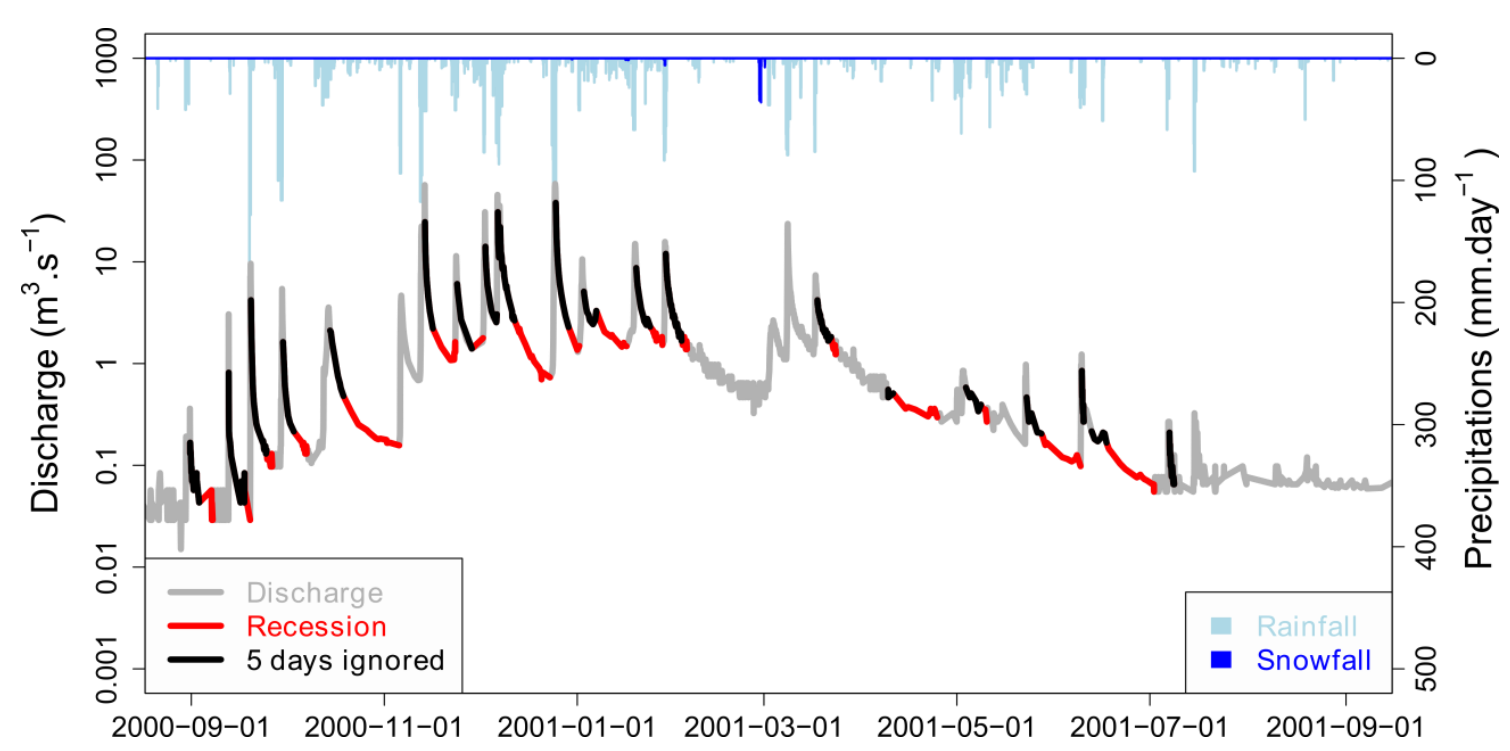

Figure 6 Streamflow recession periods extracted between 2000-09-01 and 2001-09-01 on the Auzonnet catchment (\#4, $\left.49 \mathrm{~km}^{2}\right)$. Catchment-averaged precipitation is displayed in blue on the inverted y-axis. Discharge series is shown in grey in logarithmic scale. The selected recession periods appear in red, and the first five days of recession that are ignored according to the analysis of saturation duration in upper soils are coloured in black. 


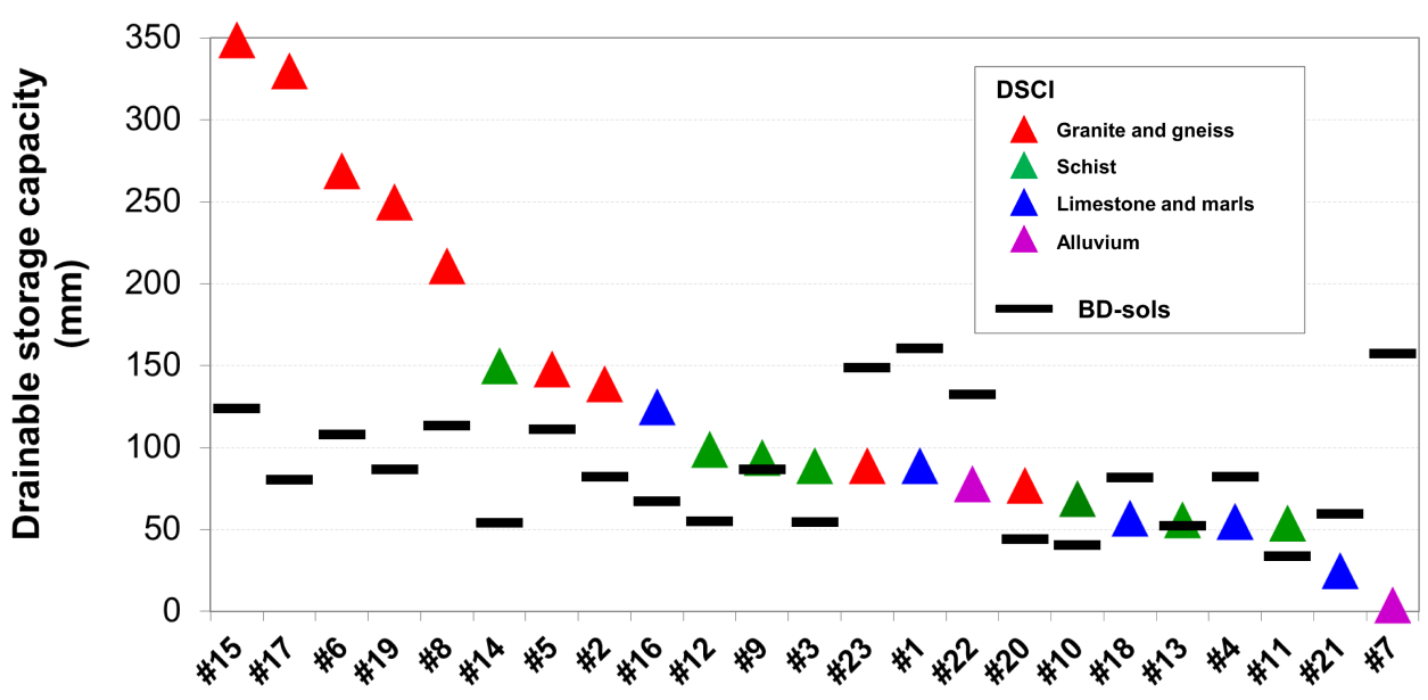

Figure 7 Ranked values of calculated DSCI for each catchment (coloured triangles) compared to drainable storage capacities estimated with the BD-sols databases (black horizontal bars). Colours correspond to the dominant geology of catchments.

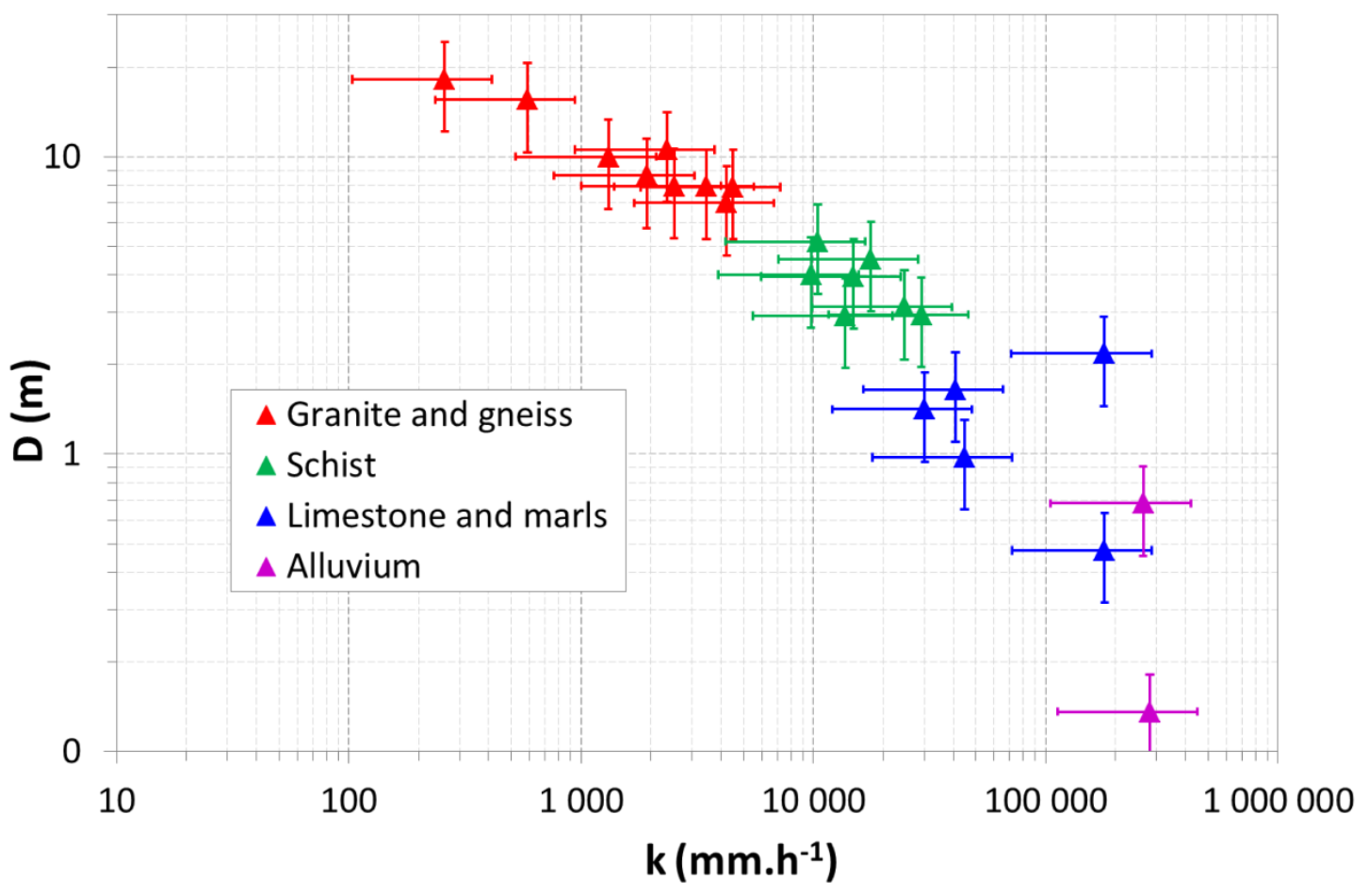

Figure 8 Depth to bedrock $D$ and lateral hydraulic conductivity $k$ calculated using streamflow recession analysis. The confidence intervals result from the uncertainty in the value of drainable porosity (between $0.05 \mathrm{~m}^{3} . \mathrm{m}^{-3}$ and $0.1 \mathrm{~m}^{3} . \mathrm{m}^{-3}$ ) 


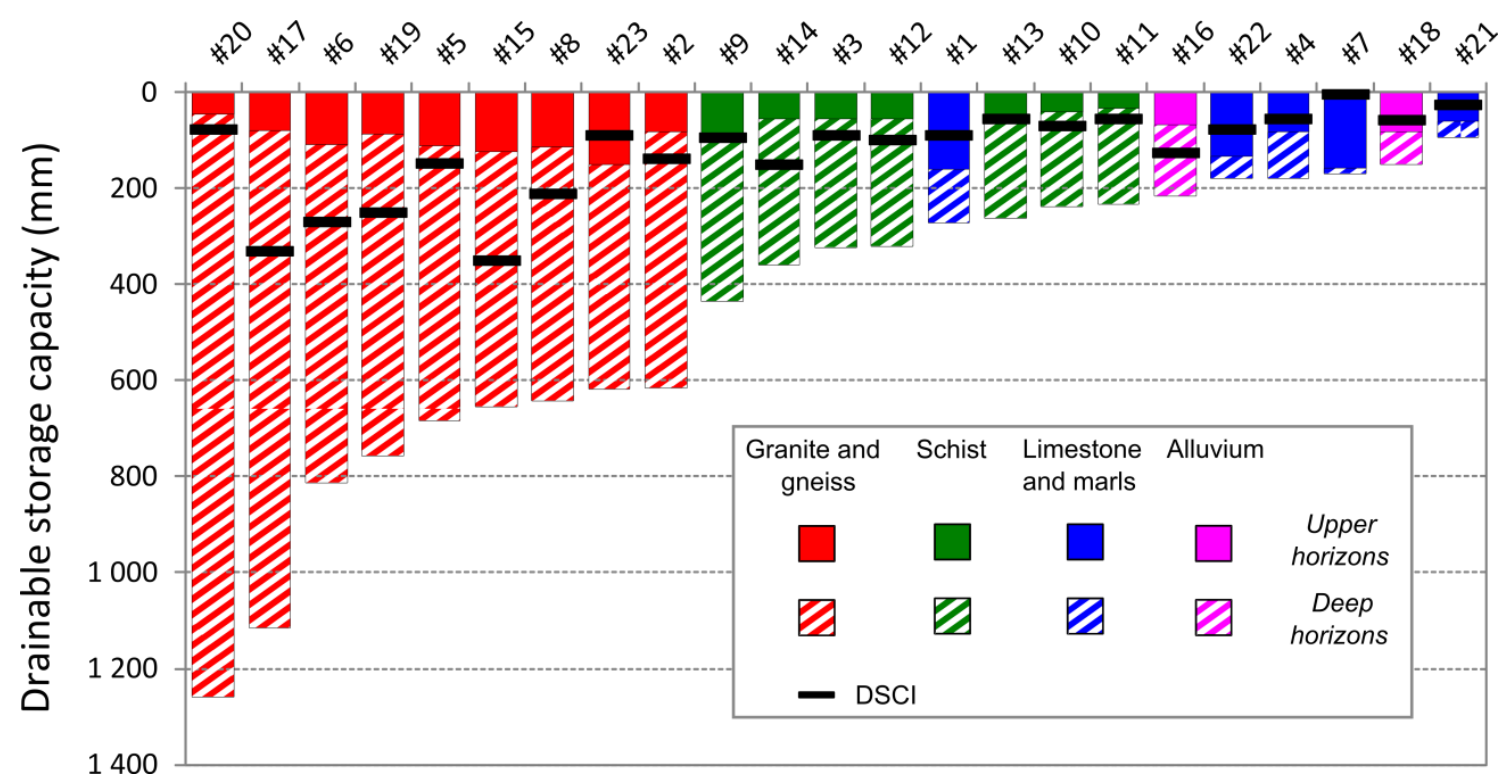

Figure 9 Total drainable storage capacities estimated for each catchment. Distinction is made between storage capacities of upper soil horizons (calculated using the BD-sols databases information) and storage capacities of deep horizons (estimated using streamflow recession analysis). The storage capacity is compared to the DSCI indicator. 